\title{
Development and Validation of a Slurry Model for Chemical Hydrogen Storage in Fuel Cell Vehicle Applications
}

\author{
Kriston P. Brooks, ${ }^{*}$ Richard P. Pires, ${ }^{\ddagger}$ and Kevin L. Simmons ${ }^{\dagger}$
}

*Energy and Environment Directorate, Pacific Northwest National Laboratory, 902 Battelle Boulevard, Richland, WA, 99352, United States, Kriston.brooks@pnnl.gov, (+15093724343) (Corresponding Author)

‡Energy and Environment Directorate, Pacific Northwest National Laboratory, 902 Battelle Boulevard, Richland, WA, 99352, United States, richard.pires@pnnl.gov, (+15093724132)

${ }^{\dagger}$ Energy and Environment Directorate, Pacific Northwest National Laboratory, 902 Battelle Boulevard, Richland, WA, 99352, United States, kevin.simmons@pnnl.gov, (+15093753651)

\section{ABSTRACT}

The U.S. Department of Energy's (DOE) Hydrogen Storage Engineering Center of Excellence (HSECoE) is developing models for hydrogen storage systems for fuel cell-based light duty vehicle applications for a variety of promising materials. These transient models simulate the performance of the storage system for comparison to the DOE's Technical Targets and a set of four drive cycles. PNNL developed models to simulate the performance and suitability of slurry-based chemical hydrogen storage materials. The storage systems of both a representative exothermic system based on ammonia borane and an endothermic system based on alane were developed and modeled in Simulink ${ }^{\circledR}$. Once complete, the reactor and radiator components of the model were validated with experimental data. The system design parameters were adjusted to allow the model to successfully meet a highway cycle, an aggressive cycle, a cold-start cycle, and a hot drive cycle. Finally, a sensitivity analysis was performed to identify the range of material properties where these DOE targets and drive cycles could be met. Materials with a heat of reaction $>11 \mathrm{~kJ} / \mathrm{mol} \mathrm{H}_{2}$ generated and a slurry hydrogen capacity of $>11.4 \%$ will meet the onboard efficiency and gravimetric capacity targets, respectively.

KEYWORDS: Hydrogen Storage, Fuel Cell Vehicles, Ammonia Borane, Alane, Systems Modeling, Sensitivity Analysis.

\section{INTRODUCTION}

Engineering of onboard hydrogen storage materials for fuel cell applications is one of the key objectives of the U.S. Department of Energy's (DOE) Hydrogen Storage Engineering Center of Excellence (HSECoE) program. The goal is to model and optimize the necessary hardware required to build hydrogen storage systems for light duty vehicle applications [1]. On the basis of their promising $\mathrm{H}_{2}$ storage capacity, ammonia borane $(A B)$ and alane have been chosen by HSECoE for the initial chemical hydride simulation studies. Several studies on the science and material properties of $A B$ and alane have been reported in the literature. Autrey and co-workers studied hydrogen release from $A B$, its thermal stability, and other 
engineering aspects [2, 3], while Aardahl et al. discuss system issues, such as heat management and reactor design, that need to be considered for vehicular storage system designs [4]. Several researchers have studied the decomposition kinetics of alane and developed kinetic expressions for hydrogen generation [5-7]. Alane also has been studied for vehicle applications [8-10], although a significant concern is its regeneration [11]. Our work at HSECoE focuses on designing, developing, and evaluating reactor systems. We use a modeling approach based on scientific knowledge for chemical hydrogen storage materials reported in the literature.

While there have been a large number of models for metal hydride storage systems reported in the literature, Pacific Northwest National Laboratory (PNNL) was the first to develop systems models of various chemical hydrogen storage materials (solid $A B$, solvated $A B$, and alane) for engineering analysis and development [12-16]. Chemical hydrogen storage materials differ from metal-hydride storage systems in that they must be removed from the vehicle before they can be regenerated by chemical processing. Metal-hydride storage materials allow direct addition of hydrogen onboard a vehicle for regeneration.

Previous studies using PNNL-developed systems assumed that the chemical hydrogen storage materials were a pelletized solid that was reacted either in place or by moving through the system using auger or pneumatic transport [12-14]. Because of the challenge of moving solid pellets through a pressurized system while preventing hydrogen loss to the environment, the use of solids has been rejected in the HSECoE. Alternatively, pure liquid systems would be ideal in terms of transport both within and outside the vehicle. Studies also have been performed assuming AB is dissolved in an ionic liquid $[15,16]$. However, successfully developing a solvated fluid at high concentration that remains a liquid both preand post-reaction has been elusive. As a result, the focus of the research for the HSECoE has been the development of these materials in a slurry form. This ongoing development work has demonstrated $A B$ slurries in silicone oil at solids concentrations up to $45 \mathrm{wt} \%$ [17] and alane in either silicone oil or mechanical pump fluid at solids concentration up to $60 \mathrm{wt} \%$. This paper focuses on the development of a system and a model describing the transient behavior of a slurry-based hydrogen storage system. The model will include both $A B$ and alane. Experimental validation of these models has been performed for two key system components. The experimental work associated with this testing will be described.

\section{SLURRY SYSTEM DESIGN}

The slurry system design on which the modeling and experimental work is based is shown in Figure 1. Details of this system and how components were selected are provided elsewhere [18], but a brief description of the process will be provided here. In this system, the slurry is transported on and off the vehicle between the filling station and a volume displacement tank. A volume displacement tank configuration minimizes the system components by requiring only one tank for both the feed and the product. A membrane separates the feed side of the tank from the product. As fresh slurry is loaded into the tank, the membrane forces spent slurry out of the tank and back to the filling station for eventual reprocessing. 
During startup, electrical resistance heaters bring the reactor walls to reaction temperature.

Meanwhile, the fresh feed in the volume displacement tank is mixed to ensure homogeneity before it is sent into the system. Once the reactor reaches the required temperature, the feed pump begins moving fresh feed into the reactor. As the slurry flows through the heated tubular reactor, hydrogen is generated in a non-catalytic thermolysis process. The hydrogen gas is separated from the three-phase mixture in a phase separator, cooled in a radiator, and then sent back to the volume exchange tank.

For the exothermic AB slurry, a fraction of the hot slurry product from the phase separator and/or cold product after the radiator can be recycled to the feed if needed. These two recycle streams preheat the feed stream to reaction temperatures while adding thermal mass to minimize the temperature excursions associated with the exothermic reaction. For the endothermic alane slurry, the feed is not recycled. Instead it passes through a recuperator to recover the heat of reaction before being cooled in the radiator.

Once the gases generated in the reactor are separated from the slurry, they pass through a coalescing filter, a radiator, and an impurities-adsorbent bed to condition the hydrogen feed prior to the fuel cell. The hydrogen must be cooled with a radiator to below $85^{\circ} \mathrm{C}$, and impurities must be removed to the levels required by SAE J2719 and ISO/PDTS 14687-2, which is $>99.97 \%$ purity [19]. Rather than heat the system quickly to meet the stringent startup time required by the DOE technical targets, hydrogen gas is stored in a ballast tank. The ballast tank allows for immediate flow of hydrogen to the fuel cell during cold startup while the storage system is warming to the required temperature to initiate the thermolysis reaction. The ballast tank also provides hydrogen to accommodate the transients during operation.

\section{SLURRY SYSTEM MODEL}

The mass and energy balances of the entire storage system described in the previous section were modeled using the Simulink ${ }^{\circledR}$ simulation software, which provides an understanding of the operational dynamics of the storage system under simulated drive-cycle scenarios. The components that are modeled are described below.

Reactor Model. The reactor for both the $A B$ and alane slurry is a tubular reactor with an internal stirrer or auger to prevent agglomeration of the solids during reaction while allowing the gas to flow through the reactor center. The parameters used for the reactor model are provided in Table 1 . For the purposes of modeling, it is assumed that the slurry is pushed to the walls of the reactor while the gas flows down the reactor center.

The fractional conversion of the chemical hydrogen storage material $(\mathrm{CH})$ to $\mathrm{H}_{2}$ in the slurry through the length of the reactor is given by $\alpha$ and is calculated as shown in Equation 1.

$$
\frac{\partial \alpha_{i}}{\partial t}=-u_{\text {slurry }} \frac{\partial \alpha_{i}}{\partial z}+\left.\frac{\partial \alpha_{i}}{\partial t}\right|_{\text {kinetics }}
$$

In the case of $A B, E q .1$ consists of two equations $(i=2)$ for the two separate polymerization reactions that correspond approximately to the first equivalent, and the second and a fraction of the third 
equivalent for a total $\mathrm{H}_{2}$ production of 2.35 equivalents. In the case of alane, Eq. 1 is a single equation producing 1.5 equivalents. The velocity of the slurry $\left(u_{\text {slurry }}\right)$ is calculated based on equation Eq. 2 :

$$
u_{\text {slurry }}=\frac{\dot{m}_{\text {slurry }}}{\rho_{\text {slurry }} A_{\text {slurry }}}+Z_{\text {auger }} v_{\text {auger }}
$$

where $Z_{\text {auger }}$ is the axial displacement of the auger per rotation, $U_{\text {auger }}$ is the rotational speed, and $A_{\text {slurry }}$ is the area of the gas/slurry interface in the reactor where the slurry channel is estimated to be $75 \%$ of the total area of the reactor calculated from $\pi\left(d_{\text {in }}^{2}-d_{\text {slurry }}^{2}\right) / 4$. As hydrogen is generated, the slurry density, $\rho_{\text {slurry, }}$ decreases to create a foamy mixture of solid, liquid, and gas with a density given in equation Eq .3.

$$
\rho_{\text {slurry }}=\frac{\dot{m}_{\text {slurry }}+\dot{m}_{H 2}}{\frac{\dot{m}_{H 2}}{\rho_{H 2}}+\frac{\dot{m}_{\text {slurry }} f_{\text {inert }}}{\rho_{\text {inert }}}+\frac{\dot{m}_{\text {slurry }} f_{C H}\left(1-\alpha_{i}\right)}{\rho_{C H}}+\frac{\dot{m}_{\text {slurry }} f_{C H} \alpha_{i}}{\rho_{C H P}}}
$$

The parameters $f_{\text {inert }}$ and $f_{\mathrm{CH}}$ are the fractions of inert and chemical hydride; and $\rho_{\mathrm{H} 2}, \rho_{\text {inert }}, \rho_{\mathrm{CH}}$, and $\rho_{\mathrm{CHP}}$ are the densities of hydrogen, slurrying agent, chemical hydride, and its product, respectively. A minimum value of the slurry density $\left(\rho_{\text {slurry,min }}\right)$ is set, and as more hydrogen is generated, it then goes into the gas phase rather than the slurry. This foaming of the slurry mixture has been observed during experiments.

The rate of change of $\alpha$ due to kinetics is given by Eq. 4, following the Kolmagorov-Johnson-Mehl-Avrami (KJMA) approach based on sigmoidal conversions as a function of time, characteristic of nucleation, and growth phenomena in solids [4].

$$
\left.\frac{\partial \alpha_{i}}{\partial t}\right|_{\text {kinetics }}=n_{i} k_{i}\left(1-\alpha_{i}\right)\left[-\ln \left(1-\alpha_{i}\right)\right]^{\left(n_{i}-1\right) / n_{i}}
$$

$k_{i}$ is the rate constant of the dehydrogenation reactions calculated by the Arrhenius expression as shown in Eq. 5.

$$
k_{i}=A_{i}^{\prime} e^{-E_{a, i} / R T}
$$

The overall hydrogen production rate $\left(r_{\mathrm{H}_{2}}\right)$ is calculated using the expression shown in Eq. 6 . The hydrogen coefficients $\left(\beta_{\mathrm{i}}\right)$ correspond to the molar ratio of hydrogen generated in each dehydrogenation reaction, $\mathrm{x}_{\mathrm{CH}}$ is the fraction of $\mathrm{CH}$ in the slurry, $\Delta \mathrm{z}$ is the length of a differential reactor section, and $\mathrm{MW}_{\mathrm{CH}}$ is the molecular weight of $\mathrm{CH}$.

$$
r_{H 2}=\left.\frac{A_{\text {slurry }} \rho_{\text {slurry }} x_{C H} \Delta z}{M W_{C H}} \sum_{i} \beta_{i} \frac{\partial \alpha_{i}}{\partial t}\right|_{\text {kinetics }}
$$


The exothermic heat generated or required from the reactions is critical to the calculation of reactor temperature and is calculated based on the reaction kinetics as shown in Eq. 7.

$$
Q_{r x n}=\left.\frac{A_{\text {slurry }} x_{C H} \rho_{\text {slurry }}}{M W_{C H}} \sum_{i} \beta_{i} \frac{\partial \alpha_{i}}{\partial t}\right|_{\text {kinetics }} \Delta H_{i}
$$

(Eq. 7)

An energy balance across the reactor is used to calculate the temperatures of the slurry in the reactor $\left(T_{\text {reactor }}\right)$, reactor wall $\left(T_{\text {metal }}\right)$, and hydrogen gas $\left(T_{\mathrm{H} 2}\right)$ as shown in Eq. 8. The model assumes convection of mass and heat but no axial conduction of heat or diffusion of mass. The source term $\left(Q_{\text {loss }}\right)$ is the total heat loss calculated from the metal to the ambient through the reactor's insulation. During reactor startup, heaters on the outer surface of the reactor walls conduct heat into the reactor $\left(Q_{\text {heater }}\right)$.

$$
\begin{aligned}
& A_{\text {slurry }} \rho_{\text {slurry }} C_{\text {pslurry }}\left(\frac{\partial T_{\text {reactor }}}{\partial t}+u_{\text {slurry }} \frac{\partial T_{\text {reactor }}}{\partial z}\right)+d_{\text {out }} \pi h_{\text {metal }}\left(T_{\text {reactor }}-T_{\text {metal }}\right)+d_{\text {in }} \pi h_{H 2}\left(T_{\text {reactor }}-T_{H 2}\right)=Q_{\text {rxn }} \\
& A_{\text {metal }} \rho_{\text {metal }} C_{p, \text { metal }}\left(\frac{\partial T_{\text {metal }}}{\partial t}\right)+d_{\text {out }} \pi h_{\text {metal }}\left(T_{\text {metal }}-T_{\text {reactor }}\right)=Q_{\text {heater }}-Q_{\text {loss }} \\
& A_{H 2} \rho_{H 2} C_{H 2}\left(\frac{\partial T_{H 2}}{\partial t}+u_{\text {gas }} \frac{\partial T_{H 2}}{\partial z}\right)+d_{i n} \pi h_{H 2}\left(T_{H 2}-T_{\text {reactor }}\right)=0
\end{aligned}
$$

The cross sectional areas of the metal and gas are calculated based their corresponding diameters. The heat transfer coefficients between the metal, the slurry, and the gas $\left(h_{\text {metal/H2/slurry }}\right)$ are calculated based on the appropriate thermal conductivities, diameters, and the Nusselt numbers. The Nusselt number for the slurry at the gas and metal interface were fitted from graphs provided for fully developed laminar flow in concentric annular ducts for uniform temperatures at both surfaces from Rohsenow et al.[20] as shown in Equations (Eq. 9-Eq. 11). The Nusselt number for the gas phase was equal to 4.36 when laminar and Equation (Eq. 11) when turbulent [21].

$$
\begin{aligned}
& N u_{\text {in }}=3.75 r^{*-0.436} \\
& N u_{\text {out }}=3+r^{*} \\
& N u_{H 2}=0.023 \operatorname{Re}_{H 2}^{0.8} \operatorname{Pr}_{H 2}^{0.4} \\
& u_{H 2}=\frac{4 \dot{m}_{H 2}}{\rho_{H 2} \pi\left(d_{\text {slurry }}^{2}-d_{\text {stir }}^{2}\right)}
\end{aligned}
$$

The value of $r^{*}$ is the ratio of the inner and outer diameter of the slurry. $\mathrm{Re}_{\mathrm{H} 2}$ and $\mathrm{Pr}_{\mathrm{H} 2}$ are the Reynolds and Prandtl numbers, respectively, for the hydrogen gas based on a gas velocity calculated from its mass flow and the area between the gas/slurry interface and the stirrer 
A variable step solver "ode23tb," available in Simulink, is used for all the simulations conducted in this work. To avoid algebraic errors in the model resulting from the reactor outputs feeding back to the controller, unit delays are used. Simulink solves the temporal components of the equations. The spatial components are solved by a series of 10 differential reactor length elements coupled together.

Kinetic Parameter Development. The Arrhenius values for $A B$ were fit based on batch reactor data. Batch reactor data of $35 \mathrm{wt} \% \mathrm{AB}$ slurries in AR-20 silicone were performed by the researchers at the University of Oregon [22]. Hydrogen production as a function of time over the range of 120 to $150^{\circ} \mathrm{C}$ is shown in Figure 3. The data were fit to obtain the rate constants as described in equation Eq. 5 and hydrogen coefficients $\left(\beta_{i}\right)$ described in equation Eq. 6 that would be used in the Simulink reactor model. The best fit with this experimental data was achieved when $\beta$ was found to be a function of temperature rather than constant (Eq. 13):

$$
\beta_{i}=\beta_{i}^{\prime} e^{-k_{i} T^{n_{i}^{\prime}}}
$$

where $\mathrm{k}^{\prime \prime}$ and $\mathrm{n}^{\prime}$ are constants to best fit the hydrogen coefficient's temperature dependence. The Arrhenius values for alane were available from the literature and were based on those previously developed by Graetz and Reilly for $\alpha$-AlH3 polymorphs [7]. In the case of alane, the $\beta$ value remained constant with temperature. As a result, no exponential fitting was required. The kinetic and hydrogen coefficient parameters for the $A B$ and alane slurry model are shown in Table 2.

Gas and Slurry Radiators. The radiator models used for both gas and slurry product cooling are based transient heat losses from the process to the radiator and from the radiator to ambient. The radiator is assumed to have finned tubes with ambient air flowing across them. The temperature distribution in the fin is assumed to be constant, while the base metal temperature varies. The model assumes transient thermal mass of the radiator with convection between the process stream $\left(T_{\text {slurry }}\right)$ and the radiator metal ( $\left.T_{\text {metal }}\right)$. Axial conduction is considered negligible. The equations used to model the process and metal temperatures are shown below in Eq. 14.

$$
\begin{aligned}
& A_{\text {interior }} \rho_{\text {slurry }} C_{p s l u r r y}\left(\frac{\partial T_{\text {slurry }}}{\partial t}+u_{\text {slurry }} \frac{\partial T_{\text {slurry }}}{\partial z}\right)+h_{\text {interior }} D_{\text {int erior }} \pi\left(T_{\text {metal }}-T_{\text {slurry }}\right)=0 \\
& A_{\text {exterior }} \rho_{\text {metal }} C_{p, \text { metal }}\left(\frac{\partial T_{\text {metal }}}{\partial t}\right)+h_{\text {interior }} D_{\text {interior }} \pi\left(T_{\text {metal }}-T_{\text {slurry }}\right)+h_{\text {exterior }} D_{\text {exterior }} \pi \delta_{\text {fin }} \eta_{\text {fin }}\left(T_{\text {metal }}-T_{\text {ambient }}\right)=0
\end{aligned}
$$

The increased surface area associated with the fin $\delta_{\text {fin }}$ can be calculated by Eq. 15 as:

$$
\delta_{\text {fin }}=\left[\left(D_{\text {fin }}{ }^{2}-D_{\text {exterior }}{ }^{2}\right)+2 D_{\text {exterior }} p_{\text {fin }}\right] /\left(2 D_{\text {exterior }} p_{\text {fin }}\right)
$$

where $D_{\text {fin }}$ is the outer diameter of the fin, $D_{\text {exterior }}$ is the outer diameter of the heat exchanger tube, $D_{\text {interior }}$ is the inner diameter of the heat exchanger tube, and $p_{\text {fin }}$ is the fin pitch. The fin efficiency $\left(\eta_{f i n}\right)$ was calculated for a circular fin as described by Rohsenow et al. [20]. The heat transfer coefficient for a 
cylinder in cross flow is calculated using on a method reported by Incropera and DeWitt [21] as shown below in Eq. 16:

$$
h_{\text {exterior }}=\frac{k_{\text {air }}^{\prime}}{D_{\text {exterior }}}\left(0.3+\frac{0.62 \operatorname{Re}_{\text {Dexterior }}^{1 / 2} \operatorname{Pr}_{\text {air }}^{1 / 3}}{\left[1+\left(0.4 / \mathrm{Pr}_{\text {air }}\right)^{2 / 3}\right]^{1 / 4}}\left[1+\left(\frac{\mathrm{Re}_{\text {Dexterior }}}{28200}\right)^{5 / 8}\right]^{4 / 5}\right)
$$

where $\operatorname{Re}_{d}=\frac{\rho_{\text {air }} u_{\text {air }} d_{h x O D}}{\mu_{\text {air }}}$ and $\operatorname{Pr}_{\text {air }}, \mathrm{k}_{\text {air }}, \mathrm{u}_{\text {air, }}, \mu_{\text {air, }}$ and $\rho_{\text {air }}$ are the Prandtl number, thermal conductivity, velocity, viscosity, and density of air at the film temperature, respectively. The value of $h_{\text {interior }}$ is calculated based on the Nusselt number for the interior of a tube with a swirl flow device for laminar flow in a uniformly heated tube as described by Rohsenow et al. [20] and shown in Eq. 17:

$$
\mathrm{Nu}_{\text {interior }}=5.172\left(1+0.005484 * \operatorname{Pr}^{0.7}\left(\operatorname{Re}_{\text {Dinterior }} / \mathrm{y}\right)^{1.25}\right)^{1 / 2}
$$

where $y$ is the twist ratio of the turbulator inside of the heat exchanger tubes. The parameters used in the radiator models are shown in Table 3. The fin is constructed from aluminum and the tube from stainless steel.

As with the reactor model, Simulink solves the temporal components of the equations while the spatial components are solved by creating a series of 10 differential elements.

System Controller. The amount of material that needs to be recycled, in addition to the material that needs to be pumped to the reactor, is regulated by a control system. The overarching goal of the controller is to regulate the flow rate of fresh slurry into the reactor based on requested hydrogen from the fuel cell and ballast tank pressure. The reactor inlet and outlet temperatures are controlled by adjusting the fraction of spent product that is recycled.

The feed flow rate is based on the hydrogen requested and the hydrogen capacity of the storage material based on complete conversion as shown in Eq. 18:

$$
\dot{m}_{\text {feed }}=\frac{\dot{n}_{H 2, \text { required }} M W_{C H}}{\left(\beta_{1}+\beta_{2}\right) x_{C H}}+\dot{m}_{P I}\left(P_{\text {ballast }}-P_{\text {setpoint }}\right)
$$

where $\dot{\mathrm{n}}_{\mathrm{H} 2 \text {, required }}$ is the molar flow of hydrogen requested from the fuel cell. To maintain the system pressure, the total hydrogen required is adjusted up or down by a proportional-integral (PI) controller. The ballast tank set point is 25 bar.

The flow of hot slurry product as recycle with the feed was adjusted to ensure that target temperature $\left(T_{\text {target }}\right)$ was met and the reaction could be initiated without requiring external heating. The flow rate of this recycle stream was calculated using Eq. 19.

$$
\dot{m}_{\text {recycle }}=\frac{\dot{m}_{\text {feed }} C p_{\text {feed }}\left(T_{t \text { arg } e t}-T_{\text {ambient }}\right)}{C p_{\text {product }}\left(T_{\text {product }}-T_{t \text { arg } e t}\right)}
$$


With the large exothermic heat release of $A B$, the temperature of the product exiting the reactor in some cases was unacceptably high. To address this problem, a fraction of the cold product from the radiator was mixed with a fraction of hot product exiting the phase separator to produce an overall larger recycle stream at the same target temperature as before. The amount of recycle flow from the radiator and phase separator is calculated using Eq. 20 and Eq. 21, respectively.

$$
\begin{gathered}
\dot{m}_{\text {productregcled }}=\frac{\dot{m}_{\text {feed }} C p_{\text {feed }}\left(T_{t \text { arg } e t}-T_{\text {ambient }}\right)+\dot{m}_{\text {recycle }} C p_{\text {product }}\left(T_{\text {targ } e t}-T_{\text {radiator }}\right)}{C p_{\text {product }}\left(T_{\text {product }}-T_{\text {radiator }}\right)} \\
\dot{m}_{\text {radiator }}=\dot{m}_{\text {recycle }}-\dot{m}_{\text {productregcled }}
\end{gathered}
$$

In this way, both constraints for a sufficient preheat and adequate dilution for maximum temperature maintenance could be met. The feed temperature target temperature is $120^{\circ} \mathrm{C}$ and the product maximum temperature is $250^{\circ} \mathrm{C}$.

With the endothermic reaction of alane, heat needs to be added to the reactor continuously. As a result, a slightly different controller for heat flux to the reactor exterior surface was implemented. Rather than just being a constant used only during startup, as is the case for the AB reactor, the heater for the alane system controller is based on the hydrogen requested and the heat of reaction of the storage material and the heat required to get to the target temperature in the form of Eq. 22 .

$Q_{\text {heater }}=\frac{\dot{n}_{H 2, \text { required }}\left(\beta_{1} \Delta H_{r x n, 1}+\beta_{2} \Delta H_{r x n, 1}\right)}{\left(\beta_{1}+\beta_{2}\right)}+\dot{m}_{\text {feed }} C_{p, \text { feed }}\left(T_{t \text { arg } e t}-T_{\text {feed }}\right)+Q_{P I}\left(T_{\text {reactor }}-T_{t \text { arg } e t}\right)$

To maintain the reactor temperature near the target value, the heat is adjusted up or down by a PI controller based on the difference between the reactor and target temperature.

Recuperator for Alane Slurry. In the case of alane, a recuperator is used to provide heat to the reactor. The recuperator is assumed to be a counterflow tube-in-tube heat exchanger. It is modeled by a series of four differential equations representing the slurry feed $\left(T_{\text {feed }}\right)$ and product temperatures $\left(T_{\text {product }}\right)$ and inner $\left(T_{\text {inner }}\right)$ and outer ( $\left.T_{\text {outer }}\right)$ wall temperatures. Heat convection is accounted for as if flows from the hot product to the inner wall to the cooler product using Eq. 23.

$$
\begin{aligned}
& A_{\text {inner }} \rho_{\text {feed }} C_{p}\left(\frac{\partial T_{\text {feed }}}{\partial t}+u_{\text {feed }} \frac{\partial T_{\text {feed }}}{\partial z}\right)+h_{\text {inner }} D_{\text {inner }} \pi\left(T_{\text {feed }}-T_{\text {inner }}\right)=0 \\
& A_{\text {innerwal }} \rho_{\text {metal }} C_{p, \text { metal }}\left(\frac{\partial T_{\text {inner }}}{\partial t}\right)+h_{\text {inner }} D_{\text {inner }} \pi\left(T_{\text {inner }}-T_{\text {feed }}\right)+h_{\text {innerwal }} D_{\text {innerwall }} \pi\left(T_{\text {inner }}-T_{\text {product }}\right)=0 \\
& A_{\text {tubeannula }} \rho_{\text {product }} C_{p}\left(\frac{\partial T_{\text {product }}}{\partial t}+u_{\text {product }} \frac{\partial T_{\text {product }}}{\partial z}\right)+h_{\text {innerwal }} D_{\text {innerwall }} \pi\left(T_{\text {product }}-T_{\text {inner }}\right)+h_{\text {outer }} D_{\text {outer }} \pi\left(T_{\text {product }}-T_{\text {outer }}\right)=0 \\
& A_{\text {outer }} \rho_{\text {metal }} C_{p, \text { metal }}\left(\frac{\partial T_{\text {outer }}}{\partial t}\right)+h_{\text {outerwall }} D_{\text {outerwall }} \pi\left(T_{\text {outer }}-T_{\text {product }}\right)=0
\end{aligned}
$$

In these equations, the cross sectional areas (A) and diameters (D) represent the inner tube (tube center) and tube annulus as well as the inner and outer of the metal tubes (Table 4). The heat transfer 
coefficient for the feed is based on the laminar, fully developed flow Nusselt number of 4.36 for constant heat flux. The heat transfer coefficients for the annulus are provided in Eq. 9 and Eq. 10. As with the reactor and the radiators, Simulink solves the temporal components of the equations while the spatial components are solved by creating a series of 10 differential elements.

Ballast Tank. The pressure of the ballast tank varies based on the tank temperature and the number of moles in the tank assuming ideal gas law. The temperature is calculated based on the temperature of the hot gases entering the ballast tank from the radiator using Eq. 24.

$$
n_{H 2 \text { total }} C_{p, H 2}\left(\frac{\partial T_{B T}}{\partial t}\right)+\dot{n}_{H 2 i n} C_{p, H 2}\left(T_{\text {radiator }}-T_{B T}\right)=0
$$

The number of moles in the tank is based on the number of moles entering the tank from the reactor and the number of moles leaving to meet the drive cycle as shown in Eq. 25.

$$
\frac{\partial n_{H 2 t o t a l}}{\partial t}=\dot{n}_{H 2 i n}-\dot{n}_{H 2 F C}
$$

To maintain hydrogen pressure above 5 bar during startup, the ballast tank volume was required to be $30 \mathrm{~L}$.

Parasitic Power. The parasitic power includes system pumps, heaters, blowers, and mixers that require electricity either continuously or periodically depending on system operations (Table 5). This parasitic power is calculated and summed throughout the model run and is used to determine the storage system onboard efficiency.

The model also predicts the storage system mass and volume based on user-inputted dimensions such as mass of the $\mathrm{CH}$, radiator length, ballast tank volume, and the reactor design. These values were estimated based on simple system designs and the weight and volume of commercial components. They are provided in Table 6 . The total system mass and volume can then be used during tradeoff studies to study impacts of the system parameters.

\section{MODEL VALIDATION EXPERIMENTS}

Once the model was developed, the reactor piece of the model developed as described above was then compared to the preliminary experimental results obtained by Los Alamos National Laboratory (LANL) using a prototypical flow through reactor scaled down from the design anticipated for automotive application. The reactor design consisted of a 1-cm inner diameter tube with a 19.1-cm long heated section. A McMaster Carr deep hole drip bit rotated at $40 \mathrm{rpm}$ inside of the tube as a means of mixing and moving the slurry through the reactor as shown in Figure 3. The reactor temperature was controlled on the outer surface over a range between 150 to $235^{\circ} \mathrm{C}$. Alane slurries between $20-60 \mathrm{wt} \%$ and $A B$ slurries at $20 \mathrm{wt} \%$ flowed through the reactor. The auger speed was adjusted between 12 and $40 \mathrm{rpm}$ and the residence time between 2.4 and 7.6 minutes. For each condition, the reactor was allowed to equilibrate and the hydrogen generation rate was measured using a calibrated flow meter. The hydrogen flow rate then was compared to the flows predicted by the model. 
The automotive dimensions and flows used in the model were scaled down to those used in the LANL experiment. The temperature within the small-scale reactor was assumed to be constant at the controlled value. Reaction enthalpies and heat losses were not included as assumed in automotive case. The tanks, heat exchangers, and other balance-of-plant components used in the automotive storage system model were removed to predict the reactor behavior. Only the minimum slurry density $\left(\rho_{\text {slurry,min }}\right)$ was adjusted to fit the experimental data. The value of $34 \mathrm{~kg} / \mathrm{m}^{3}$ for alane was fit to the data in a least squares regression analysis. Using this minimum density value, the coefficient of determination was calculated to be $90 \%$ for 12 data points fit in Table 7.

The data include a range of solids loadings, residence times, auger speeds, and reaction temperatures. There is reasonably good fit between the model and the experiment over the range of conditions. Using the parameters obtained from the data set modeled in Table 6, a separate set of alane data were fit with the model. These data were obtained for a $20 \mathrm{wt} \%$ slurry, residence time of 6.8 minutes, and an auger speed of $40 \mathrm{rpm}$ over a temperature range of 150 to $275^{\circ} \mathrm{C}$. The results of this data fit are shown in Figure 4. While the fit is reasonably good, the model does tend to slightly under-predict hydrogen generation rates at the low temperatures and over-predict them at the higher temperatures.

This same model was also used to fit the experimental data developed for AB. Only three data points at $20 \mathrm{wt} \%$ solids were measured due to difficulties in pumping the AB slurry. In this case, the density of the slurry product of $370 \mathrm{~kg} / \mathrm{m}^{3}$ was measured and used in the model as the minimum slurry density ( $\left.\rho_{\text {slurry,min }}\right)$. The model predicted the experiment accurately at $150^{\circ} \mathrm{C}$, the maximum temperature of the batch data, but did not extrapolate well to higher temperature values (Figure 5). As a result, the kinetic parameters were adjusted to fit these three experimental data points. These updated kinetic parameters are shown in Table 8 and are used for all subsequent analysis.

Radiator Testing. Validation of the radiator models was performed using eight finned heat exchangers in series assembled into a rectangular configuration as shown in Figure 6. These finned tubes produced by Energy Transfer MDE were made from $0.95 \mathrm{~cm}$ diameter stainless steel tubes with a total length of $2.43 \mathrm{~m}$. The aluminum fins brazed onto the tube were $0.76 \mathrm{~cm}$ tall and $0.046 \mathrm{~cm}$ thick, and were spaced $5.5 \mathrm{fins} / \mathrm{cm}$. Inside the tube was a stainless steel turbulator with a pitch of $7.6 \mathrm{~cm}$ per revolution. Ambient air at $\sim 29^{\circ} \mathrm{C}$ was blown through this radiator at a constant rate of $6 \mathrm{~m} / \mathrm{s}$.

Because of the cost of both the raw materials and the preparation of $\mathrm{CH}$ slurries, a simulant was developed to be used in the radiator test to match that of an $A B$ slurry instead of using reacted $\mathrm{CH}$ materials. A $40 \mathrm{wt} \%$ polyimide (P84-N, 10 to 59 microns) slurry in the AR-20 silicone oil was selected as a good physical simulant, and it modeled a spent $40 \mathrm{wt} \% \mathrm{AB}$ slurry reasonably well. The simulant slurry concentration was selected because it matched the viscosity of the product - both were $\sim 200 \mathrm{cP}$ with a shear stress of $1 \mathrm{~Pa}$. The simulant slurry had a higher wt\% and vol\% solids than the AB slurry, but it bound both of these values. The two-phase system was selected to tolerate the elevated temperatures and pressures required for the validation testing.

The polyimide slurry was electrically heated in a stirred feed vessel to between 150 and $230^{\circ} \mathrm{C}$. Once the set point was reached, the slurry was pumped through the radiator at between 44 and $263 \mathrm{~g} / \mathrm{min}$, and 
the inlet and outlet temperatures across the heat exchanger were measured. The model results were then compared to the experimental results as shown in Figure 7. The good fit between the model and experimental indicates that the model is adequately validated.

Validation of Other Components. In addition to the reactor and radiator, other components were validated as part of this project. These components include the volume displacement tank, the phase separator, and the impurities clean-up system. These components require validation as part of the system development, but complete phase separation and impurities clean-up is assumed in the model. As a result their validation is not critical to the modeling effort and is provided elsewhere [18].

\section{SIMULATION RESULTS}

A variable step solver "ode23tb" is used in Simulink to solve the model for all studies performed in this work. To avoid algebraic errors in the model resulting from reactor outputs feeding back to the controller, unit delays are used. To demonstrate the usefulness of the simulation for real vehicle driving scenarios, transient simulations using various drive cycles were run. The test matrix was provided by our HSECOE partners to test various storage system models developed by team partners [17] and includes 1) a highway cycle (UDDS + HWFET), 2) an aggressive driving cycle (USO6), 3) a cold-start cycle (cold FTP), and 4) a hot cycle (SCO3-Hot). The hydrogen demand data from the fuel cell was provided by the National Renewable Energy Laboratory, an HSECoE partner [23]. All drive-cycle simulations were successfully implemented into the model but for conciseness, only important simulation results are provided in this paper. All the drive cycles were repeated until the DOE-required $5.6 \mathrm{~kg}$ of usable hydrogen was produced.

The US06 drive cycle, the most aggressive drive cycle considered in this study, was used as the hydrogen requirement input to the model. As is consistent with all drive cycles, the pressure in the ballast tank shows an initial decrease with no hydrogen being generated while the reactor is being heated to temperature as shown in Figure 8. This first 2-3 minutes of the US06 drive cycle determines the size of the ballast tank. The tank must be large enough to maintain the hydrogen pressure above 5 atm during startup. Once the reaction is initiated, the hydrogen pressure in the ballast tank varies only slightly around the $25 \mathrm{~atm}$ set point until the slurry is consumed and the ballast tank pressure is lost.

Although the USO6 drive cycle reaches hydrogen usage of up to 0.8 moles $\mathrm{H} 2 /$ second ( $80 \mathrm{kWe}$ ), the storage system ballast tank provides a buffer. As a result, with a $50 \mathrm{wt} \% \mathrm{AB}$ slurry for example, the

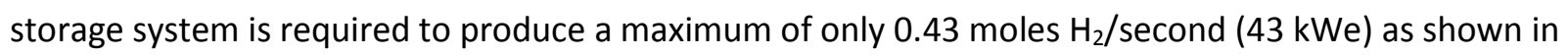
Figure 9. The alane system is required to produce a maximum of 0.32 moles $\mathrm{H}_{2} /$ second ( $\left.32 \mathrm{kWe}\right)$. This significantly reduces the system's size and capacity requirements. During startup, an electric heater brings the reactor to temperature before the reaction is initiated. During the entire operation, electric pumps and mixers are used to maintain the flow and ensure homogeneity of the slurry mixture. All of these electrical components result in parasitic loss of hydrogen that cannot be used for primary automotive propulsion. The DOE has given the requirement for $90 \%$ onboard efficiency. Based on the amount of electrical power required and using $0.02 \mathrm{~g} \mathrm{H}_{2} / \mathrm{s} / \mathrm{kWe}$ conversion of hydrogen to electrical power, the onboard efficiency was calculated using Eq. 26: 


$$
\text { Efficiency }=\frac{m_{H 2, \text { total }}-m_{H 2, \text { parasitics }}}{m_{H 2, \text { total }}}
$$

where $m_{H 2, t o t a l}$ is the mass of hydrogen generated by the system and $m_{H 2 \text {,parasitics }}$ is the amount of hydrogen that must be converted to electrical power for parasitic losses. For the US06 drive cycle as well all other drive cycles studied with $50 \mathrm{wt} \% \mathrm{AB}$, the onboard efficiency is predicted to be $>95 \%$. In contrast, the onboard efficiencies for $50 \%$ alane are predicted to be $87-93 \%$. The alane reaction is endothermic, and as a result, it requires reactor heating during the entire operations. In contrast, $A B$ produces enough heat that no reactor heating is required. Reactor heating is the major parasitic loss in the alane system. Such components as the volume displacement tank, phase separator, and impurities clean-up system do not impact the on-board efficiency of the system since they do not require power for their operation.

The high hydrogen requirement of the USO6 also results in the most stringent case for the storage system radiators. As shown in Figure 1, there is one radiator to cool the separated hydrogen and one for the spent slurry. The DOE targets require that the hydrogen going to the fuel cell be maintained at a temperature $<85^{\circ} \mathrm{C}$. There is not a specific target for the cooling required for the slurry, but at sustained temperatures $>60^{\circ} \mathrm{C}$, the fresh $\mathrm{CH}$ that is in contact with the spent $\mathrm{CH}$ through only a membrane in the volume displacement tank will begin to generate hydrogen. As a result, the slurry and hydrogen radiators have been sized to maintain their exit temperature less than the required values. The temperatures of the hydrogen and slurry for both $A B$ and alane are shown in Figures 10 and 11, respectively. As can be seen from these results, startup produces the highest hydrogen exit temperature for both $A B$ and alane and for the $A B$ exit slurry temperature. In contrast the slurry temperature for alane increases over time.

The model demonstrated that the storage system as designed could meet the drive-cycle requirements for both alane and $A B$ for the other three drive cycles as well. Similar results were obtained for the other drive cycles and will not be provided here.

The system mass and volume also were calculated as part of this modeling effort. Based on the current designs, the $A B$ system has a mass and volume of $126 \mathrm{~kg}$ and $133 \mathrm{~L}$, respectively. For hydrogen production of $5.6 \mathrm{~kg}$, the gravimetric and volumetric capacities calculated for the AB system are $0.044 \mathrm{~kg}$ $\mathrm{H}_{2} / \mathrm{kg}$ system and $0.042 \mathrm{~kg} \mathrm{H} / \mathrm{L}$ system. The alane system, in contrast, has a mass and volume of $172 \mathrm{~kg}$ and $153 \mathrm{~L}$, respectively. For hydrogen production of $5.6 \mathrm{~kg}$, the gravimetric and volumetric capacities calculated for the alane system are $0.033 \mathrm{~kg} \mathrm{H}_{2} / \mathrm{kg}$ system and $0.037 \mathrm{~kg} \mathrm{H}_{2} / \mathrm{L}$ system. The primary difference in the mass and volume between these two systems is the additional mass and volume of $\mathrm{CH}$ required for the alane system. Neither $A B$ nor alane systems meet the 2017 DOE technical targets for gravimetric and volumetric capacities of $0.055 \mathrm{~kg} \mathrm{H}_{2} / \mathrm{kg}$ system and $0.04 \mathrm{~kg} \mathrm{H}_{2} / \mathrm{L}$ system. Additional evaluation of these systems relative to the technical targets is provided elsewhere $[18,24]$.

\section{SENSITIVITY ANALYSIS}


The DOE does not assume that $A B$ or alane slurries will be the materials ultimately used in vehicles. It is assumed that additional chemical hydrogen storage material discovery and development will be performed. As a result, one of the purposes of the model is to help guide potential material developers regarding the range of material properties that could be implemented successfully into a chemical storage system similar to what was developed here. To this end, the model also was used to perform a sensitivity analysis and better understand the impact of the material properties being able to meet the DOE targets. The models were run for 3000 seconds using five US06 drive cycles back-to-back. Key material properties were varied individually around the values used in the model described above until one of the DOE targets was not met or the model could not run successfully.

Key parameters of a hydrogen storage material are heat of reaction, hydrogen capacity, and reaction rate. These parameters were explored for both alane and $A B$ as surrogates for possible future hydrogen storage materials. The heat of reaction was varied for these two materials and the results were evaluated. For either exothermic or endothermic materials, as the heat of reaction moves further away from zero, the reactor temperature increases. This results in higher ballast tank and product tank temperatures. At some point, temperatures may become excessive. In addition, as the reaction heat becomes increasingly exothermic, the onboard efficiency and conversion decrease as well. Based on the results of the model, onboard efficiency drops below the DOE technical target value of $90 \%$ at 11 $\mathrm{kJ} / \mathrm{mol} \mathrm{H}_{2}$ as shown in Figure 12.

The hydrogen capacity of the material impacts the onboard efficiency and gravimetric and volumetric capacity. Lower hydrogen capacity decreases the onboard efficiency, similar to the heat of reaction. Values of $\sim 3.75 \%$ hydrogen for an alane slurry and $2.7 \mathrm{wt} \%$ hydrogen for an AB slurry result in $<90 \%$ onboard efficiency. More significantly, the gravimetric density is decreased with low hydrogen capacity. For both $A B$ and alane, the DOE technical target gravimetric factor of 0.055 can be met at hydrogen capacities of $>11.4 \%$ (See Figure 13). The system mass was similar for both systems in spite of their differences. For a $50 \mathrm{wt} \%$ slurry, this would require $125 \%$ and $50 \%$ increases in hydrogen capacity for alane and $A B$, respectively, relative to their current values. Previous sensitivity analyses indicate that the volumetric capacity will be met when the gravimetric capacity is achieved.

An increase in reaction kinetics above their current values has little effect on the drive-cycle performance or the system parameters. Similarly, decreasing the reaction kinetics has little impact as well up to the point that conversion becomes so poor that the drive cycle cannot be met. This point occurs at $\sim 50 \%$ of the reaction rate of $A B$ and $\sim 2 \%$ of the reaction rate of alane.

\section{CONCLUSIONS}

To determine the feasibility of chemical hydride materials for onboard hydrogen storage for transportation based fuel cell applications, representative models were developed for exothermic and endothermic slurry systems. Ammonia borane and alane were chosen as the materials for proof-ofconcept studies, and the results were compared to experimental data for a flow-through reactor system and a prototypical radiator. The fits between the model results and the experimental results were good for both components, providing validation of the models. 
Once validated, these models were evaluated relative to the DOE technical targets and a set of four drive cycles. Preliminary observations from the simulations include 1) the drive cycles could be met for both the exothermic and endothermic models, 2) both systems will require higher hydrogen capacity than is possible for a $50 \mathrm{wt} \%$ slurry to meet the DOE gravimetric capacity target of $0.055 \mathrm{~kg} \mathrm{H} / \mathrm{kg}$ system, and 3) the DOE onboard efficiency target of $90 \%$ can be met for all exothermic reaction enthalpies and for endothermic reaction enthalpies $<11 \mathrm{~kJ} / \mathrm{mol} \mathrm{H}_{2}$.

\section{ACKNOWLEDGMENTS}

This work was done at PNNL, as a part of the Hydrogen Storage Engineering Center of Excellence (HSECOE) project, sponsored by the U.S. Department of Energy. Special thanks to Troy Semelsberger (Los Alamos National Laboratory) for providing flow-through reactor kinetics data and Dr. Shih-Yuan Liu (Boston College) for providing batch kinetics data. PNNL is operated by Battelle for DOE under contract DE-AC05-76RLO1830.

\section{REFERENCES}

[1] DOE Fuel Cell Technology Program, in, www.hydrogen.energy.gov, Accessed May 2014.

[2] A. Gutowska, L.Y. Li, Y.S. Shin, C.M.M. Wang, X.H.S. Li, J.C. Linehan, R.S. Smith, B.D. Kay, B. Schmid, W. Shaw, M. Gutowski, T. Autrey, Angewandte Chemie-International Edition, 44 (2005) 3578-3582.

[3] S.D. Rassat, R.S. Smith, C.L. Aardahl, T. Autrey, A.A. Chin, J.W. Magee, G.R. VanSciver, F.J. Lipiecki, Abstracts of Papers of the American Chemical Society, 232 (2006).

[4] S.D. Rassat, C.L. Aardahl, T. Autrey, R.S. Smith, Energy \& Fuels, 24 (2010) 2596-2606.

[5] I.M.K. Ismail, T. Hawkins, Thermochimica Acta, 439 (2005) 32-43.

[6] P.J. Herley, O. Christofferson, Journal of Physical Chemistry, 85 (1981) 1887-1892.

[7] J. Graetz, J.J. Reilly, Journal of Physical Chemistry B, 109 (2005) 22181-22185.

[8] T.Q. Hua, R.K. Ahluwalia, International Journal of Hydrogen Energy, 36 (2011) 15259-15265.

[9] G. Sandrock, J. Reilly, J. Graetz, W.M. Zhou, J. Johnson, J. Wegrzyn, Applied Physics a-Materials Science \& Processing, 80 (2005) 687-690.

[10] R.K. Ahluwalia, T.Q. Hua, J.K. Peng, International Journal of Hydrogen Energy, 34 (2009) 7731-7740.

[11] J. Graetz, S. Chaudhuri, J. Wegrzyn, Y. Celebi, J.R. Johnson, W. Zhou, J.J. Reilly, Journal of Physical Chemistry C, 111 (2007) 19148-19152.

[12] M.N. Devarakonda, J.D. Holladay, K.P. Brooks, S.D. Rassat, D.R. Herling, Polymer Electrolyte Fuel Cells 10, Pts 1 and 2, 2010, pp. 1959-1972.

[13] K. Brooks, M. Devarakonda, S. Rassat, J. Holladay, Journal of Fuel Cell Science and Technology, 8 (2011). 
[14] K. Brooks, M. Devarakonda, S. Rassat, D. King, D. Herling, Asme, Proceedings of the Asme 8th International Conference on Fuel Cell Science, Engineering, and Technology 2010, Vol 1, (2010) 729-734.

[15] M. Devarakonda, K. Brooks, E. Ronnebro, S. Rassat, International Journal of Hydrogen Energy, 37 (2012) 2779-2793.

[16] M. Devarakonda, K. Brooks, E. Ronnebro, S. Rassat, J. Holladay, SAE World Congress and Exhibition, SAE Technical Paper 2012-01-1229 (2012).

[17] Y.J. Choi, E.C.E. Ronnebro, S. Rassat, A. Karkamkar, G. Maupin, J. Holladay, K. Simmons, K. Brooks, Physical Chemistry Chemical Physics, 16 (2014) 7959-7968.

[18] K. Brooks, T. Semelsberger, K. Simmons, B. van Hassel, Journal of Power Sources, 268 (2014) 950959.

[19] Office of Energy Efficiency and Renewable Energy and The FreedomCAR and Fuel Partnership, in, http://www1.eere.energy.gov/hydrogenandfuelcells/storage/pdfs/targets_onboard_hydro_storage_exp lanation.pdf, 2009, Accessed May 2014.

[20] W.M. Rohsenow, J.P. Hartnett, Y.I. Cho, Handbook of Heat Transfer, 3rd Ed. ed., McGraw Hill, Boston, MA, 1998.

[21] F. Incropera, D. DeWitt, Fundamentals of Heat and Mass Transfer, 2nd Ed. ed., John Wiley \& Sons, New York, NY, 1985.

[22] Personal Communication to S. Liu, University of Oregon, 2013.

[23] Personal Communication to K. Day, National Renewable Energy Laboratory, 2010.

[24] T. Semelsberger, K. Brooks, Journal of Power Sources, Pending Publication (2014).

NOMENCLATURE

$\begin{array}{ll}\text { A } & \text { area }\left(\mathrm{m}^{2}\right) \\ \mathrm{A}^{\prime} & \text { Arrhenius factor }\left(\mathrm{s}^{-1}\right) \\ \mathrm{C} & \text { concentration }(\mathrm{ppm}) \\ \mathrm{Cp} & \text { heat capacity }(\mathrm{J} / \mathrm{kg} / \mathrm{K}) \\ \mathrm{D} & \text { radiator diameter }(\mathrm{m}) \\ \mathrm{d} & \text { reactor diameter }(\mathrm{m}) \\ \mathrm{E}_{\mathrm{a}} & \text { activation energy }(\mathrm{J} / \mathrm{mol}) \\ f & \text { mass fraction } \\ \mathrm{h} & \text { heat transfer coefficient }\left(\mathrm{W} / \mathrm{m}^{2} / \mathrm{K}\right) \\ \mathrm{k} & \text { reaction rate }\left(\mathrm{s}^{-1}\right) \\ \mathrm{k}^{\prime} & \text { thermal conductivity }(\mathrm{W} / \mathrm{m} / \mathrm{K}) \\ \mathrm{k}^{\prime \prime} & \text { constant for } \beta \text { calculation }\left(1 /{ }^{\circ} \mathrm{C}\right) \\ \mathrm{L} & \text { length }(\mathrm{m}) \\ \dot{m} & \text { mass flow rate }(\mathrm{kg} / \mathrm{s}) \\ \mathrm{M} & \text { mass of } \mathrm{CH}(\mathrm{kg})\end{array}$




\begin{tabular}{|c|c|}
\hline MW & molecular weight of chemical hydride \\
\hline$\dot{n}$ & molar flow rate $(\mathrm{mol} / \mathrm{s})$ \\
\hline $\mathrm{n}$ & exponent /moles of hydrogen \\
\hline $\mathrm{Nu}$ & Nusselt Number \\
\hline$P$ & pressure (atm) \\
\hline$p_{\text {fin }}$ & fin pitch \\
\hline $\operatorname{Pr}$ & Prandtl Number \\
\hline$Q$ & heat $(\mathrm{kW} / \mathrm{m})$ \\
\hline$r^{*}$ & ratio of inner and outer diameter of slurry \\
\hline $\mathrm{R}$ & universal gas constant $(\mathrm{J} / \mathrm{mol} / \mathrm{K})$ \\
\hline $\operatorname{Re}$ & Reynolds Number \\
\hline $\mathrm{T}$ & temperature (K) \\
\hline $\mathrm{t}$ & time $(s)$ \\
\hline u & velocity (m/s) \\
\hline V & volume (L) \\
\hline$x$ & mass fraction \\
\hline$y$ & turbulator twist ratio \\
\hline $\mathrm{z}$ & axial distance $(\mathrm{m})$ \\
\hline Z & axial displacement per revolution (m) \\
\hline$\alpha$ & extent of reaction \\
\hline$\beta$ & stoichiometric ratio of hydrogen to $\mathrm{CH}$ \\
\hline$\beta^{\prime}$ & constant for calculating $\beta$ as a function of $T$ \\
\hline$\delta_{\text {fin }}$ & surface area ratio for the radiator fins \\
\hline$\Delta \mathrm{H}$ & reaction enthalpy $\left(\mathrm{kJ} / \mathrm{mol} \mathrm{H}_{2}\right)$ \\
\hline$\mu$ & viscosity $\left(\mathrm{N}-\mathrm{s} / \mathrm{m}^{2}\right)$ \\
\hline$\eta$ & fin efficiency \\
\hline$v$ & rotational speed (rpm) \\
\hline$\rho$ & density $\left(\mathrm{kg} / \mathrm{m}^{3}\right)$ \\
\hline
\end{tabular}

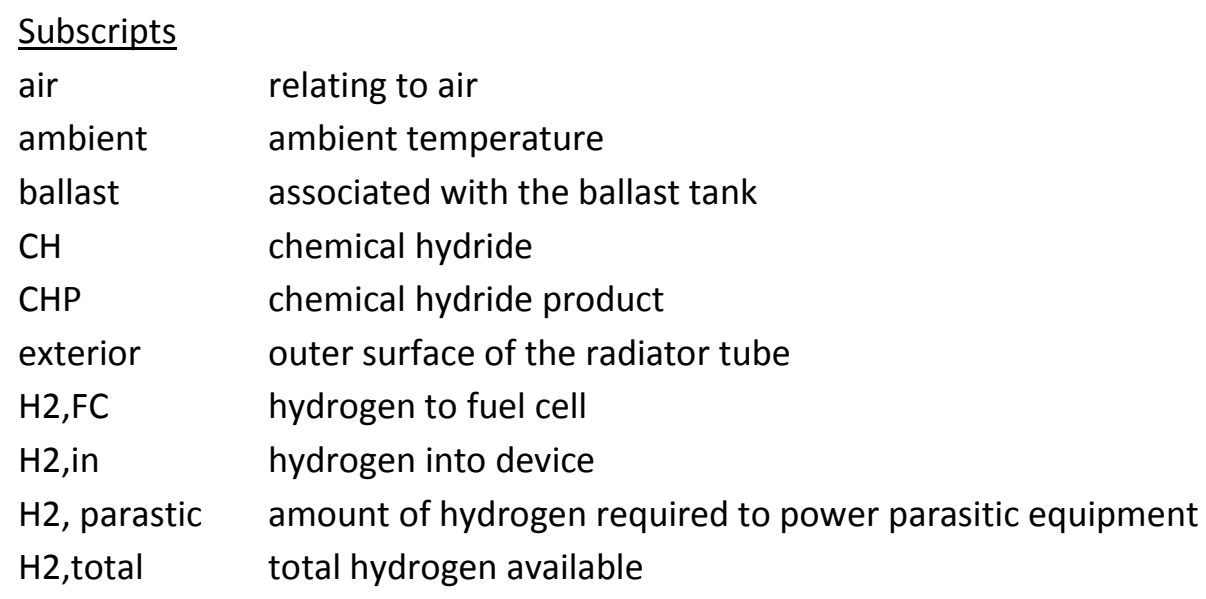




$\begin{array}{ll}\text { feed } & \text { feed } \\ \text { fin } & \text { fin dimensions } \\ \mathrm{H}_{2} & \text { hydrogen gas } \\ \text { heater } & \text { heater } \\ \text { i } & \text { reaction number (e.g. 1,2) } \\ \text { in } & \text { inner diameter reactor } \\ \text { inner } & \text { inner diameter of recuperator inner tube } \\ \text { inert } & \text { inert material (slurrying agent) } \\ \text { innerwall } & \text { outer wall of recuperator inner tube } \\ \text { interior } & \text { inner surface of the radiator tube } \\ \text { loss } & \text { heat loss } \\ \text { metal } & \text { metal for reactor or radiator } \\ \text { min } & \text { minimum allowable value } \\ \text { out } & \text { outer diameter reactor } \\ \text { outer } & \text { inner wall of the outer recuperator tube } \\ \text { outerwall } & \text { outer wall of the outer recuperator tube } \\ \text { PI } & \text { proportional-integral controller value } \\ \text { product } & \text { associated with product } \\ \text { product recycle associated with cold product from radiator recycled back to reactor } \\ \text { radiator } & \text { associated with the radiator } \\ \text { reactor } & \text { associated with the reactor } \\ \text { required } & \text { hydrogen requested from the fuel cell } \\ \text { recycle } & \text { associated with hot product recycle back to reactor } \\ \text { rxn } & \text { reaction property } \\ \text { set point } & \text { associated with a set point value } \\ \text { slurry } & \text { slurry } \\ \text { stir } & \text { reactor stirrer } \\ \text { target } & \text { associated with a target value } \\ \end{array}$




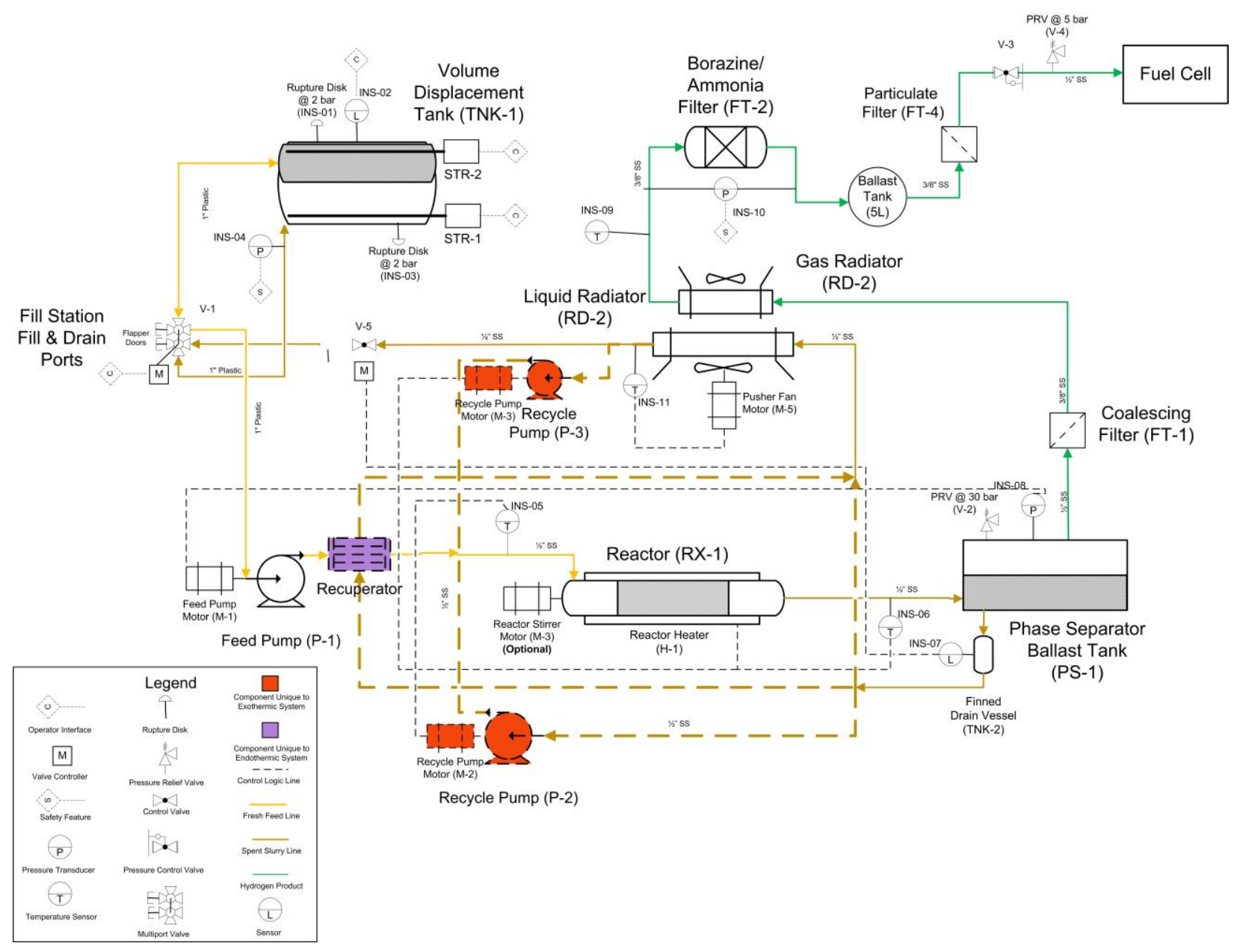




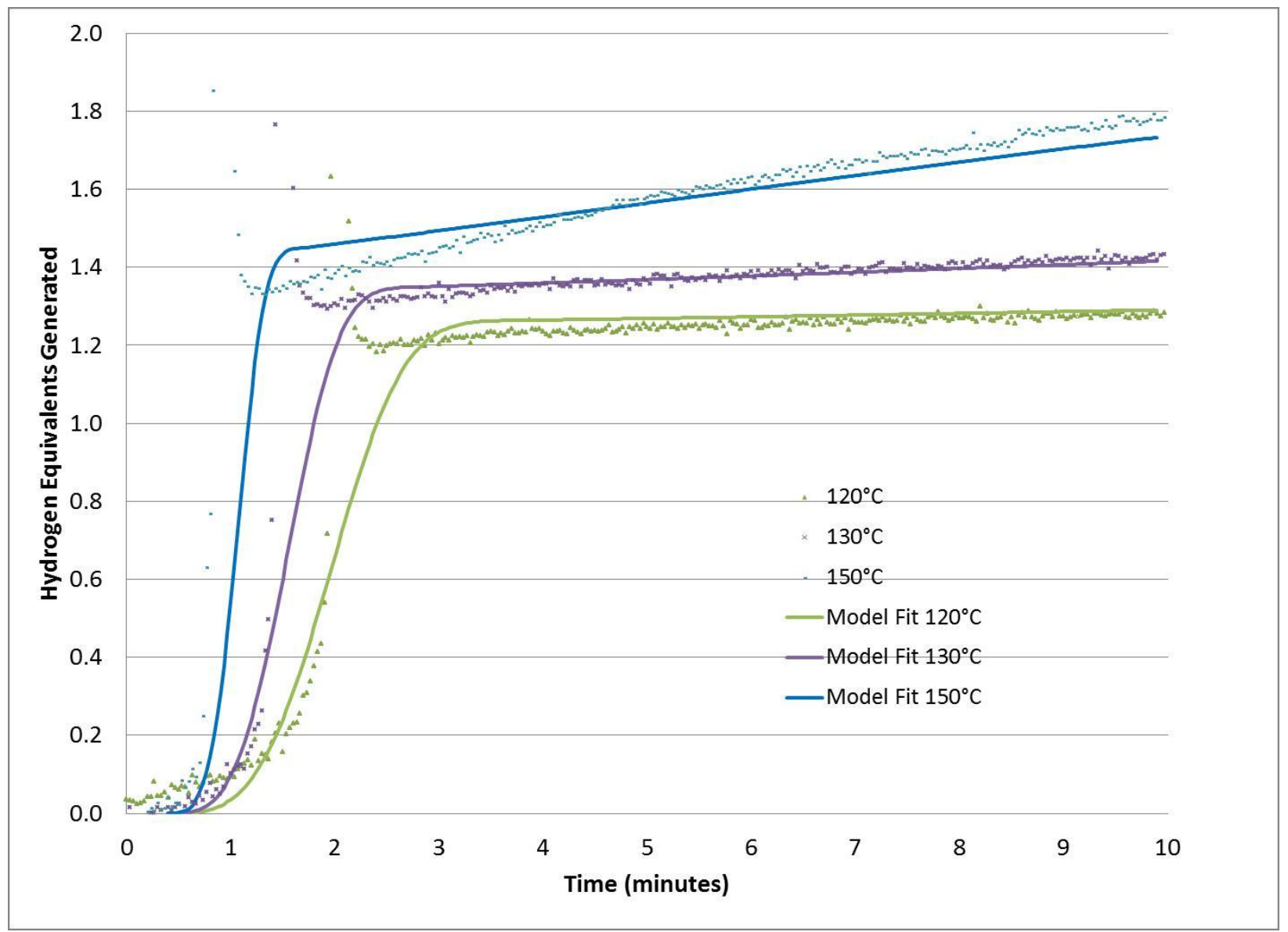




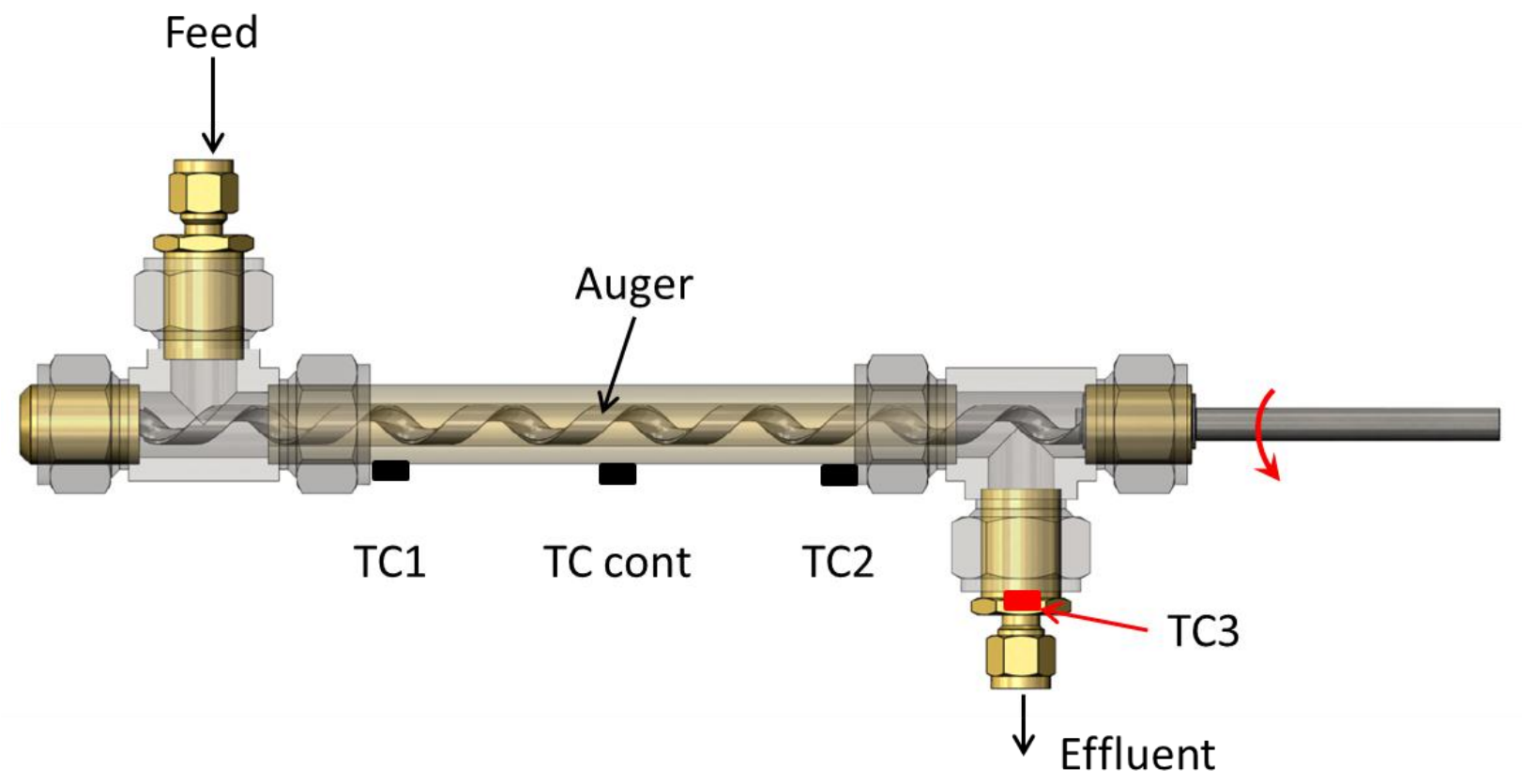




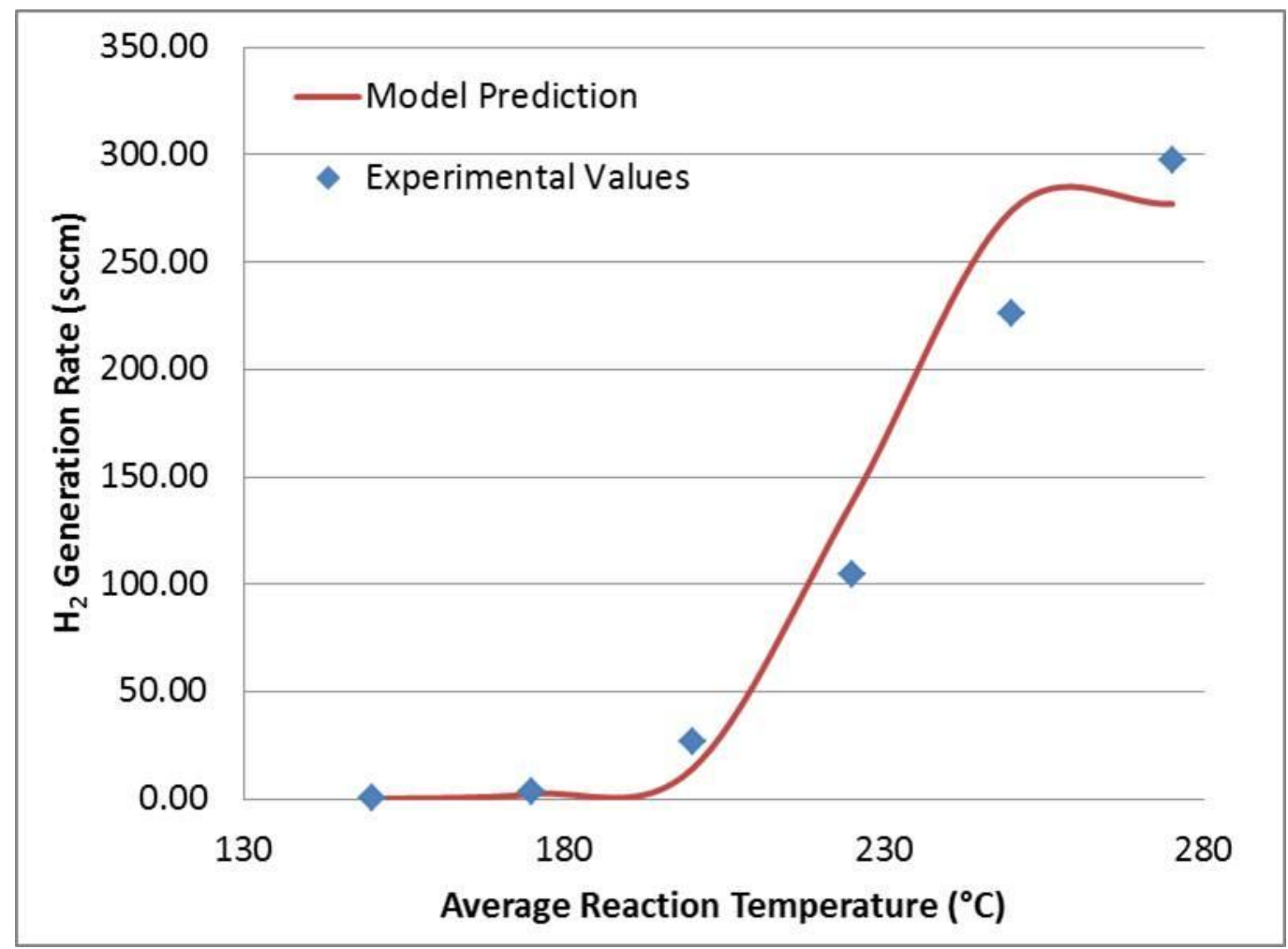




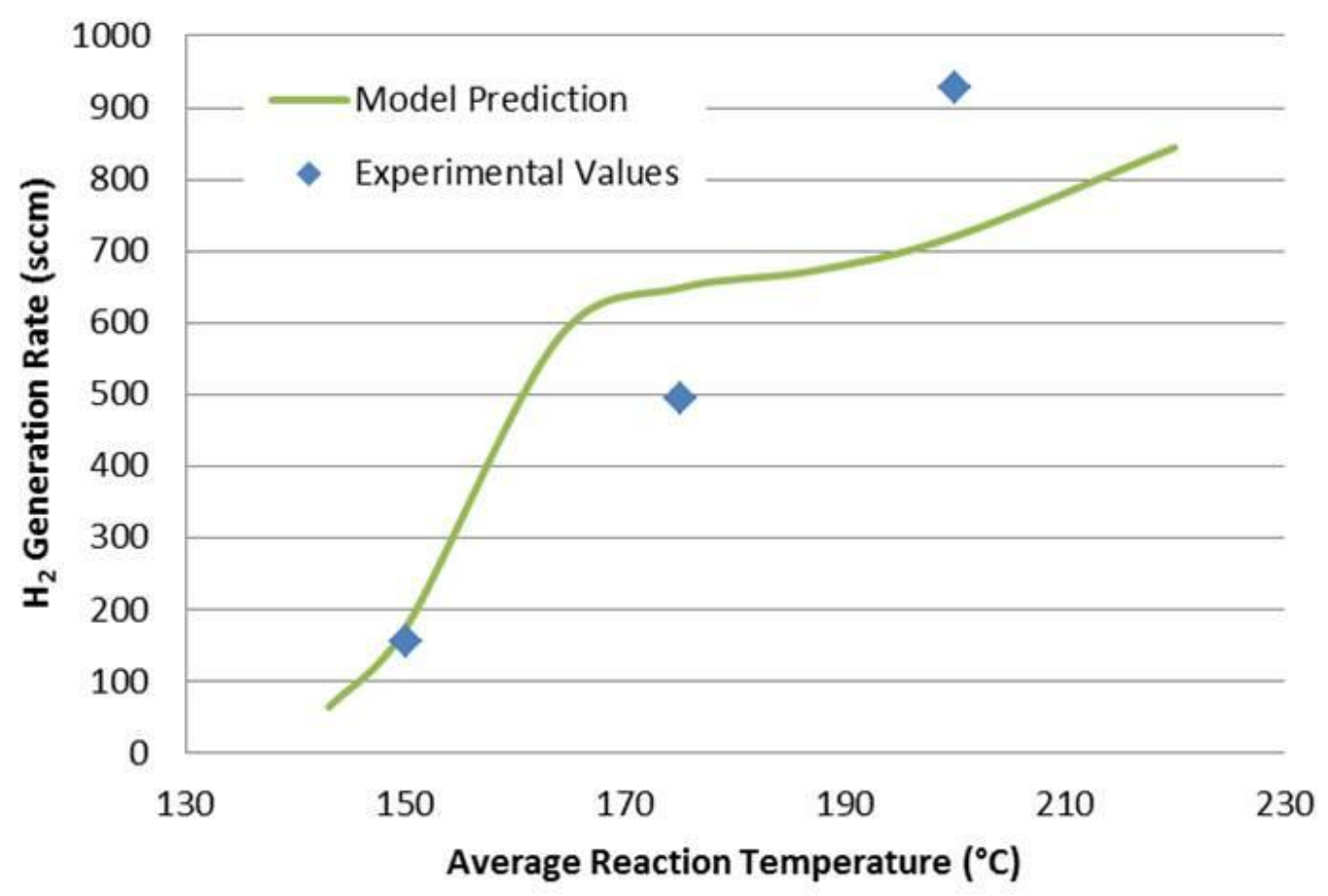




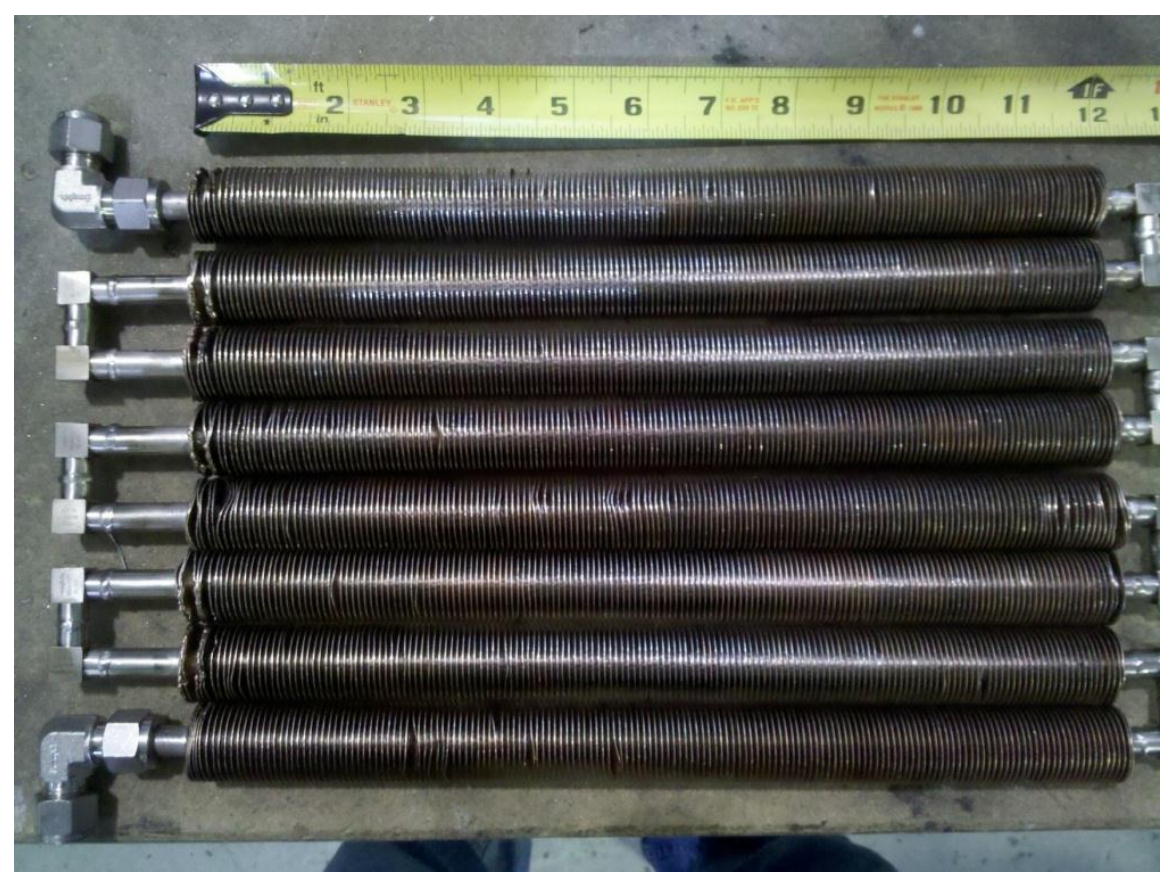




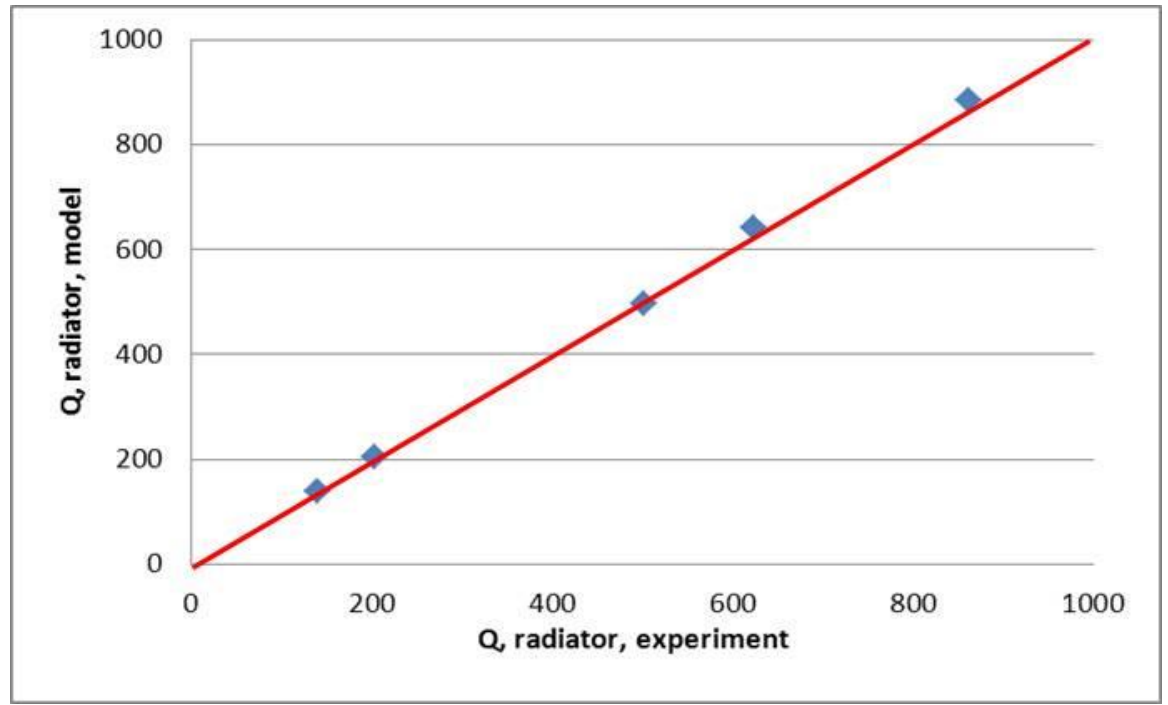




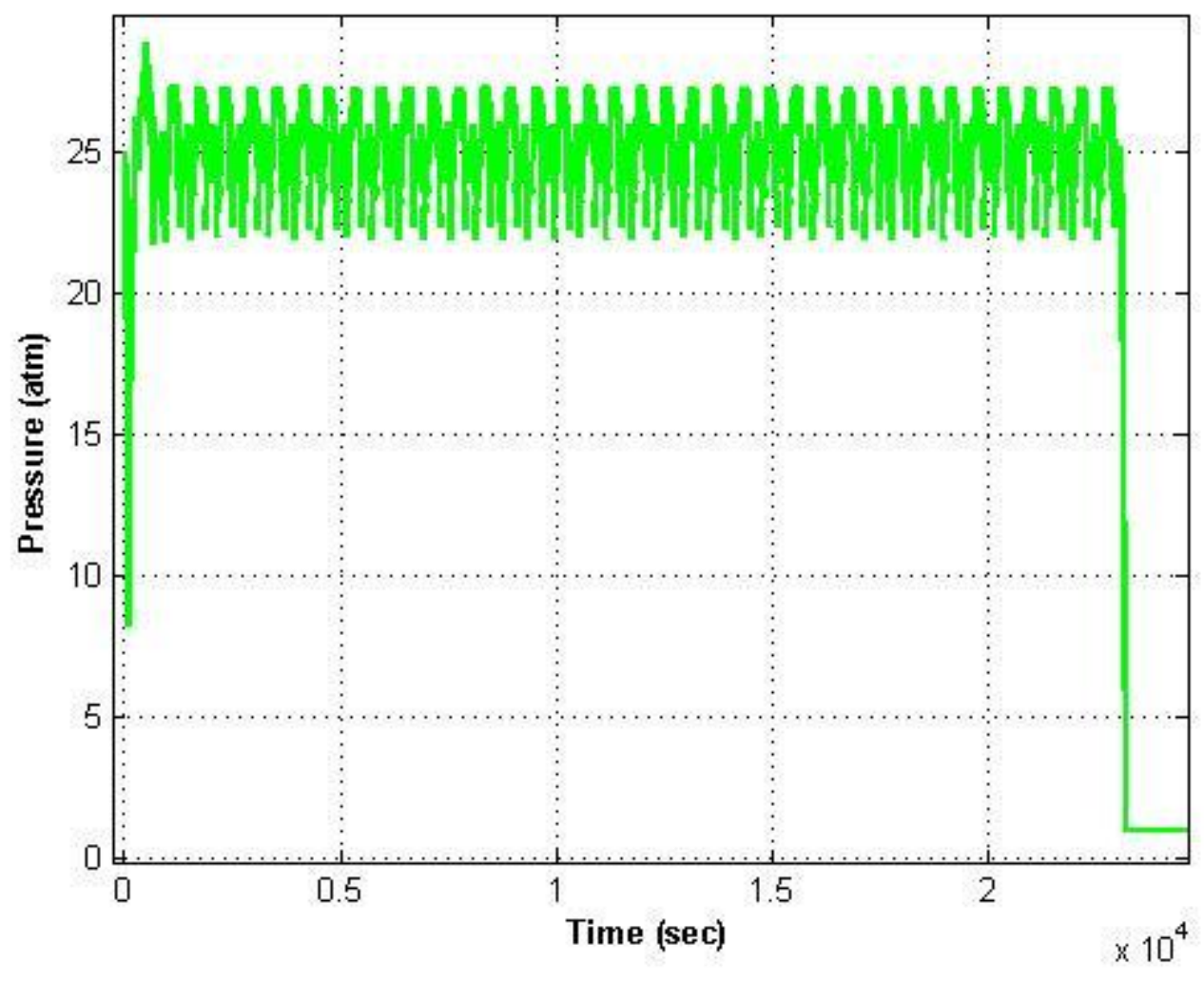




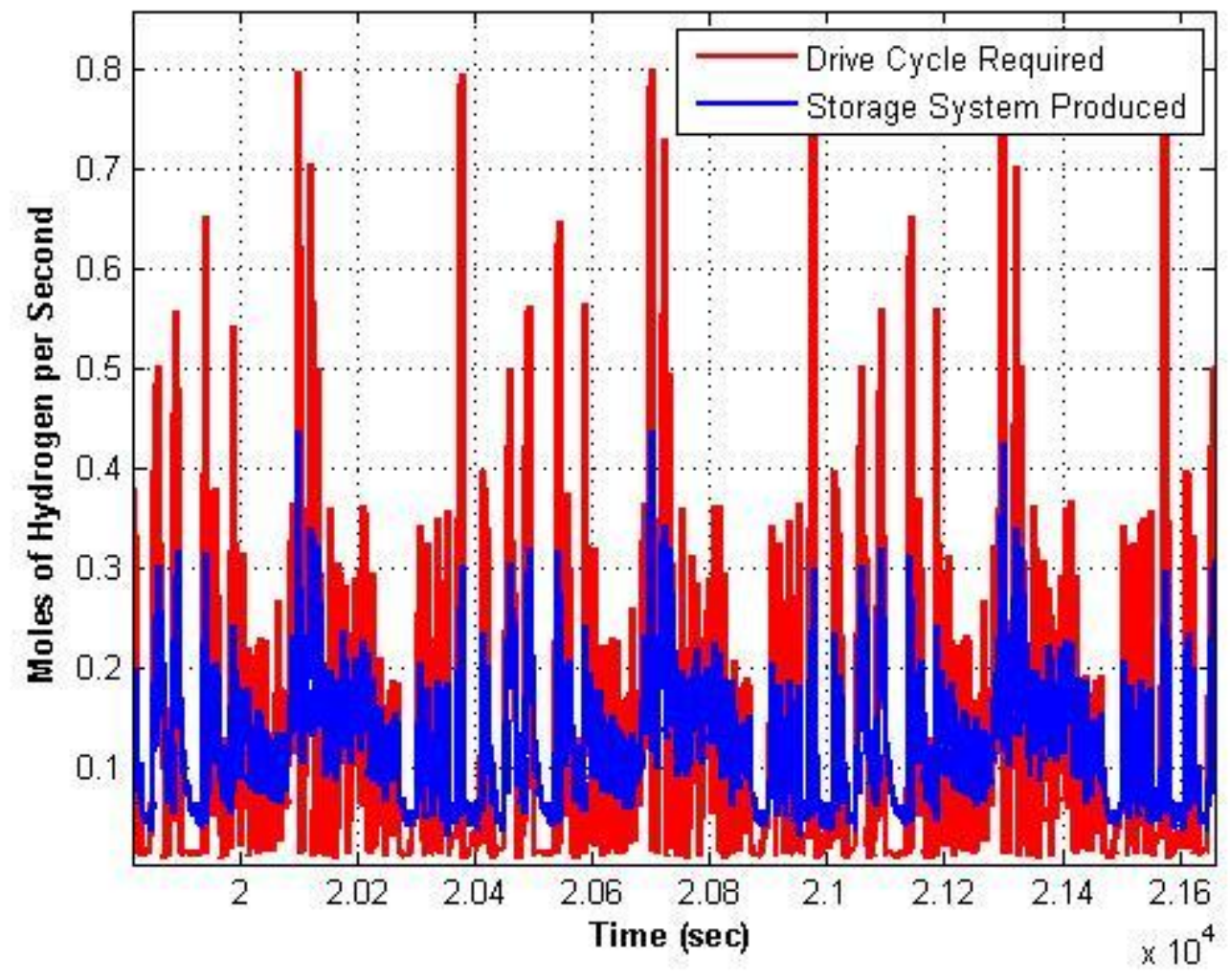




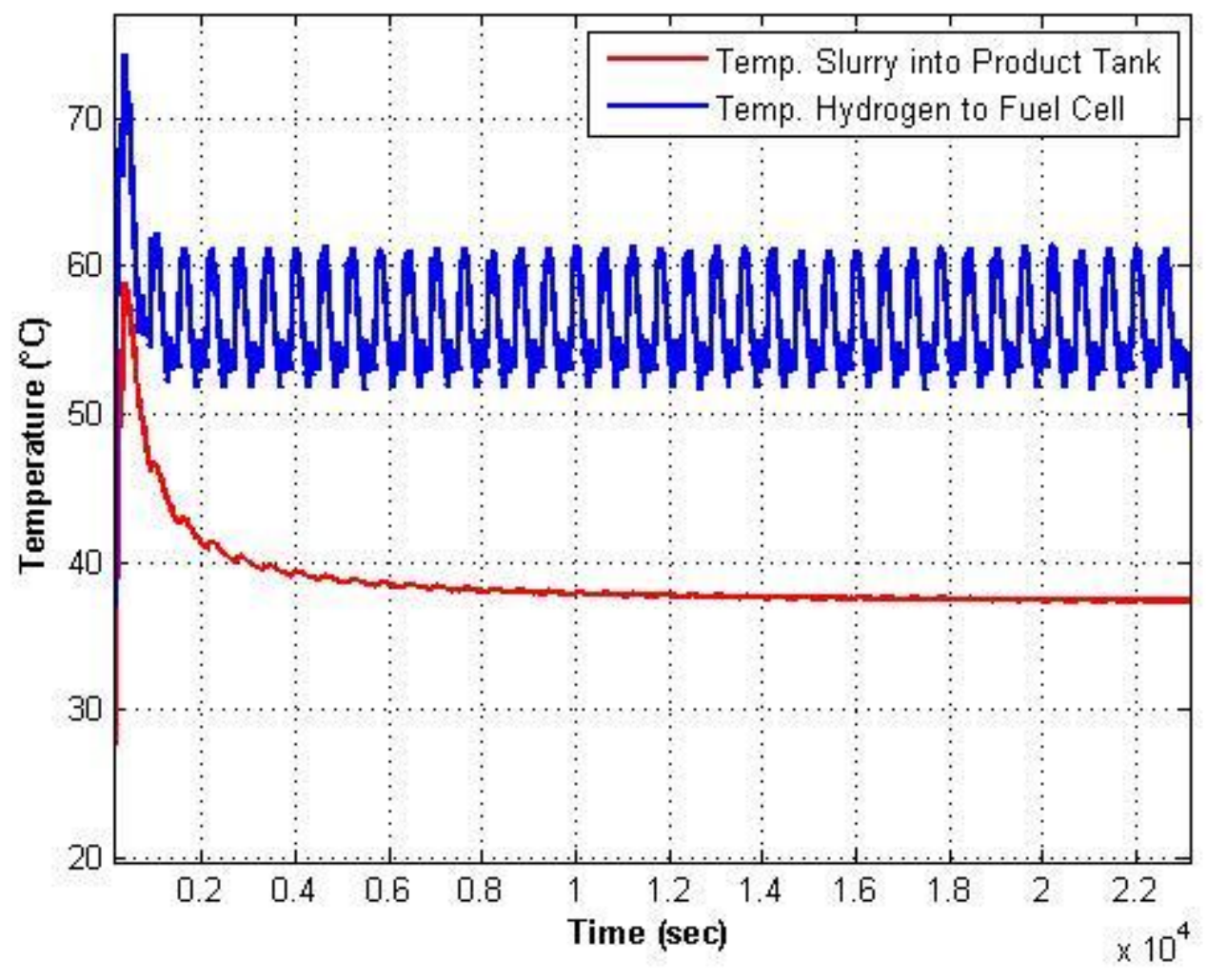




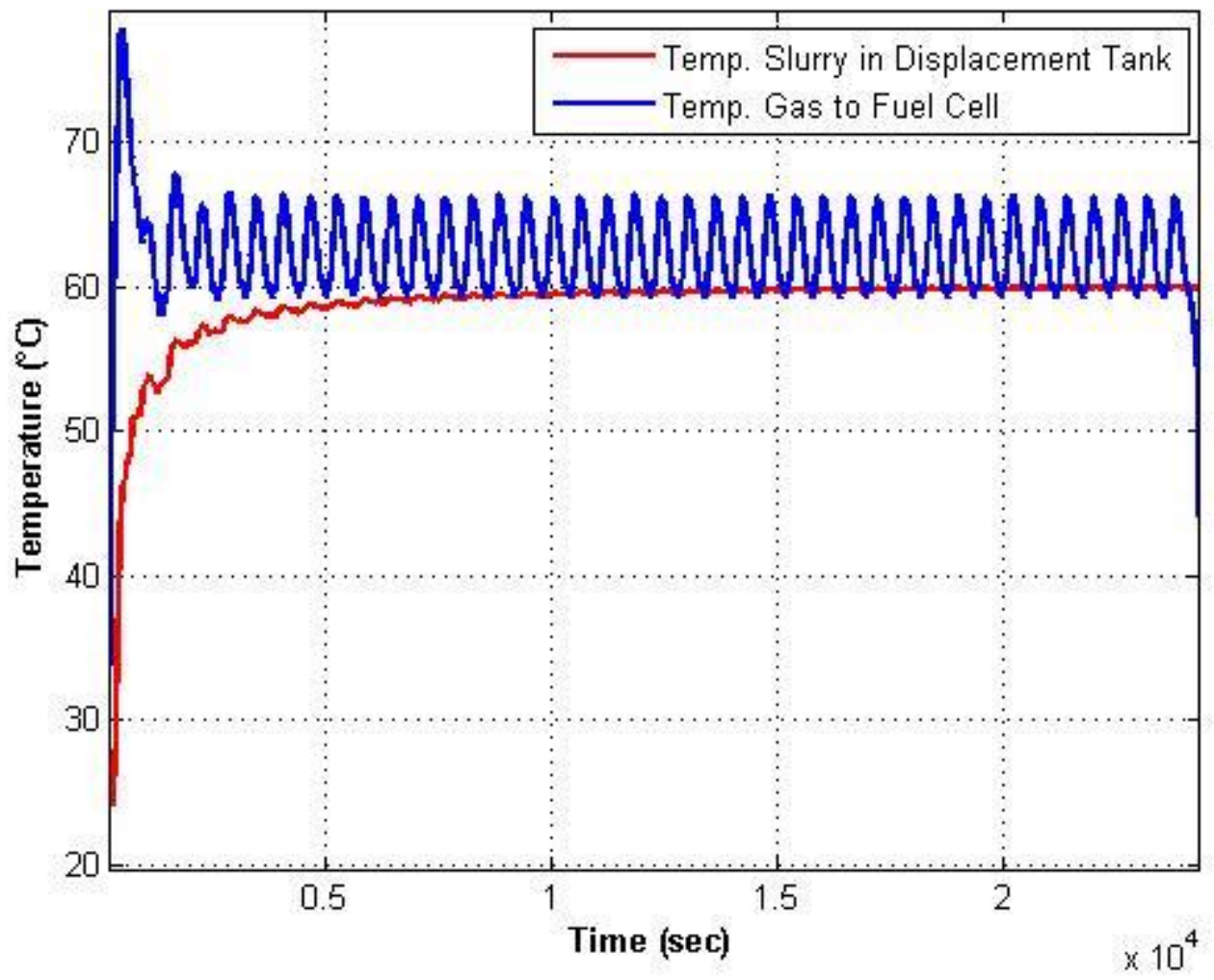




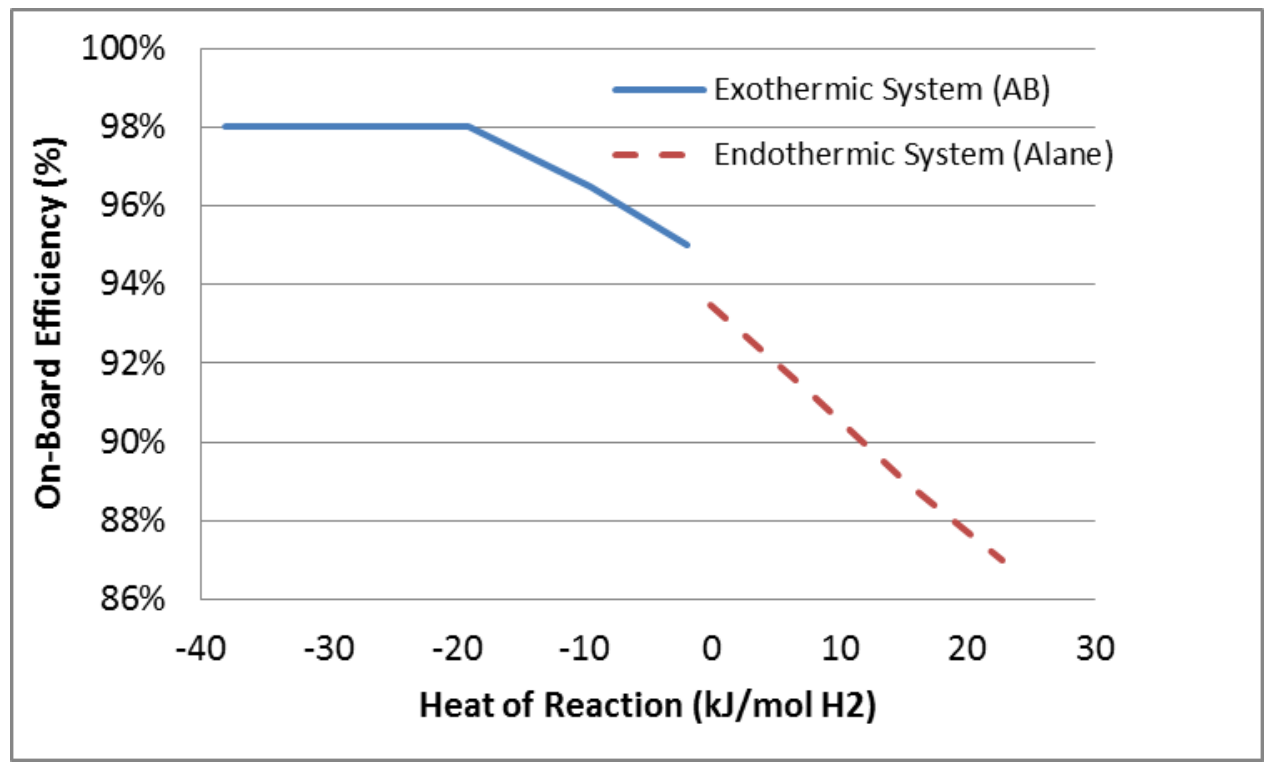




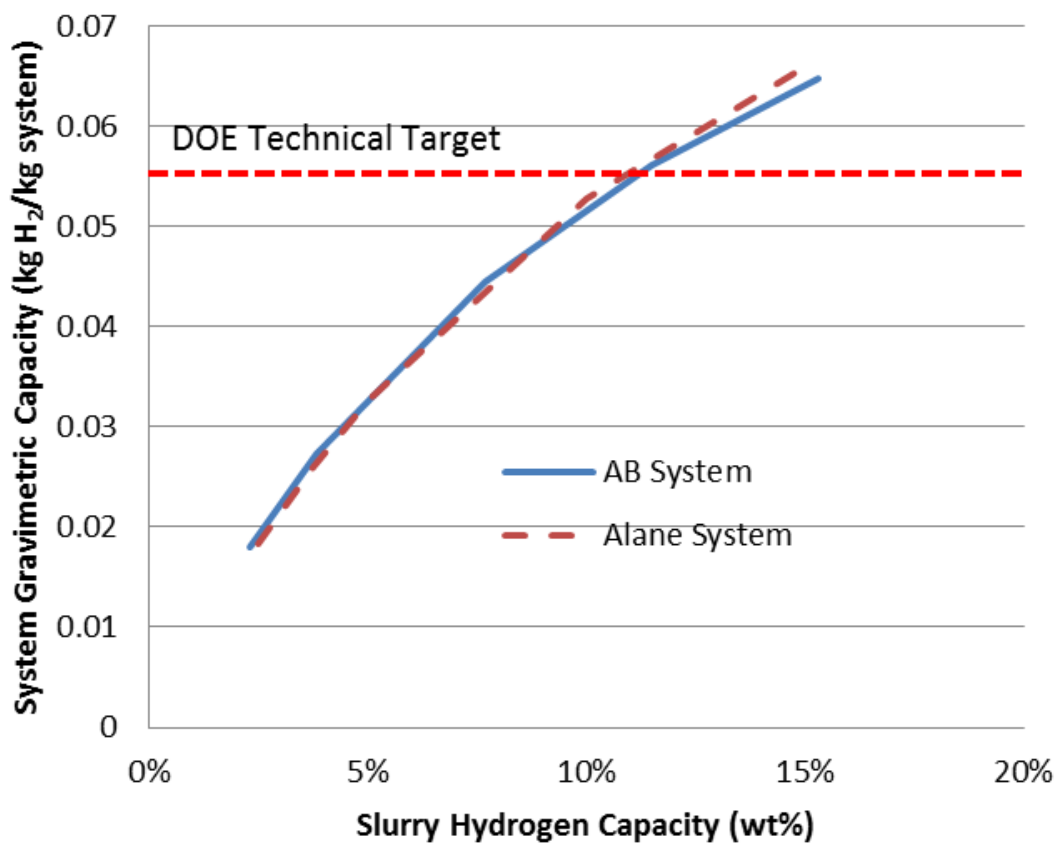




\section{Tables}

Table 1

\begin{tabular}{|c|c|c|c|c|c|}
\hline Reactor Parameters & Value & Units & AB Parameters & Value & Units \\
\hline Reactor Outer Diameter $\left(\mathrm{d}_{\text {out }}\right)$ & $4.44 \times 10^{-2}$ & $\mathrm{~m}$ & AB Bulk density $\left(\rho_{\text {bulk }}\right)$ & 780 & $\mathrm{~kg} / \mathrm{m}^{3}$ \\
\hline Reactor Inner Diameter $\left(\mathrm{d}_{\text {in }}\right)$ & $4.11 \times 10^{-2}$ & $\mathrm{~m}$ & Molecular weight $\mathrm{AB}\left(\mathrm{MW}_{\mathrm{CH}}\right)$ & 30.8 & $\mathrm{~g} / \mathrm{mol}$ \\
\hline Reactor Stirrer Diameter $\left(\mathrm{d}_{\mathrm{stir}}\right)$ & $4.76 \times 10^{-3}$ & $\mathrm{~m}$ & Heat of Reaction $1^{\text {st }}$ Eq. $\left(\Delta H_{1}\right)$ & 15 & $\mathrm{~kJ} / \mathrm{mol} \mathrm{H}_{2}$ \\
\hline $\mathrm{CH}$ fraction in slurry $\left(\mathrm{x}_{\mathrm{CH}}\right)$ & 0.5 & wt frac & Heat of Reaction $2^{\text {nd }}$ Eq. $\left(\Delta H_{2}\right)$ & 22 & $\mathrm{~kJ} / \mathrm{mol} \mathrm{H}_{2}$ \\
\hline \multirow[t]{2}{*}{ Start-up Heater ( $\left.Q_{\text {neater }}\right)$} & 8 & $\mathrm{~kW} / \mathrm{m}$ & Heat capacity slurry $\left(\mathrm{C}_{\mathrm{pbulk}}\right)$ & 2694 & $\mathrm{~J} / \mathrm{kg} / \mathrm{K}$ \\
\hline & & & Reactor Length $(A B)$ & 0.5 & m \\
\hline Density Metal $\left(\rho_{\text {metal }}\right)$ & 8000 & $\mathrm{~kg} / \mathrm{m}^{3}$ & Alane Parameters & Value & Units \\
\hline Heat capacity metal $\left(C_{p, \text { metal }}\right)$ & 480 & $\mathrm{~J} / \mathrm{kg} / \mathrm{K}$ & Slurry bulk density $\left(\rho_{\text {bulk }}\right)$ & 1486 & $\mathrm{~kg} / \mathrm{m}^{3}$ \\
\hline Slurry Thermal Conductivity $\left(\mathrm{k}_{\mathrm{CH}^{\prime}}\right)$ & 2.0 & $\mathrm{~W} / \mathrm{m} / \mathrm{K}$ & Molecular weight Alane $\left(\mathrm{MW}_{\mathrm{CH}}\right)$ & 30 & $\mathrm{~g} / \mathrm{mol}$ \\
\hline Silicone Oil Density & 1070 & $\mathrm{~kg} / \mathrm{m}^{3}$ & Heat of Reaction $\left(\Delta H_{1}\right)$ & -7.6 & $\mathrm{~kJ} / \mathrm{mol} \mathrm{H}_{2}$ \\
\hline \multirow[t]{2}{*}{ Silicone Oil Heat Capacity } & 1846 & $\mathrm{~J} / \mathrm{kg} / \mathrm{K}$ & Heat capacity slurry $\left(C_{p b u l k}\right)$ & 1000 & $\mathrm{~J} / \mathrm{kg} / \mathrm{K}$ \\
\hline & & & Reactor Length (Alane) & 2.0 & $\mathrm{~m}$ \\
\hline
\end{tabular}

Table 2

\begin{tabular}{|c|c|c|c|c|}
\hline \multirow[b]{2}{*}{ Parameter } & \multirow[b]{2}{*}{ Units } & \multicolumn{2}{|c|}{ AB } & \multirow[b]{2}{*}{ Alane } \\
\hline & & $1^{\text {st }}$ Equivalent & $2^{\text {nd }} / 3^{\text {rd }}$ Equivalent & \\
\hline Arrhenius Factor (Ai) & $\mathrm{s}^{-1}$ & $9.6 \times 10^{3}$ & $8.8 \times 10^{7}$ & $1.2 \times 10^{10}$ \\
\hline Activation Energy (Ei) & $\mathrm{kJ} / \mathrm{mol}$ & 45.0 & 89.1 & 102.2 \\
\hline $\mathrm{H}_{2}$ Coefficient Constant $\left(\beta_{\mathrm{i}}{ }^{\prime}\right)$ & $\mathrm{mol} \mathrm{H}_{2} / \mathrm{mol} \mathrm{AB}$ & 1.45 & 0.905 & 1.5 \\
\hline Beta Constant $\left(\mathrm{k}_{\mathrm{i}}{ }^{\prime}\right)$ & $\left(1 /{ }^{\circ} \mathrm{C}\right)^{\mathrm{ni}^{\prime}}$ & $1.29 \times 10^{-6}$ & $1.62 \times 10^{-7}$ & 0 \\
\hline Beta Temperature Exponent $\left(n^{\prime}{ }_{i}\right)$ & unitless & 2.98 & 3.84 & 1 \\
\hline $\mathrm{H}_{2}$ Coefficient Exponent $\left(\mathrm{n}_{\mathrm{i}}\right)$ & unitless & 3.1 & 1.2 & 2 \\
\hline
\end{tabular}

Table 3

\begin{tabular}{|c|c|c|c|c|c|}
\hline Slurry Parameter & Value & Units & Gas Parameter & Value & Units \\
\hline Fin Diameter $\left(\mathrm{d}_{\mathrm{fin}}\right)$ & 0.025 & $\mathrm{~m}$ & Fin Diameter $\left(\mathrm{d}_{\mathrm{fin}}\right)$ & 0.016 & $\mathrm{~m}$ \\
\hline $\begin{array}{l}\text { Heat Exchanger Tube Diameter } \\
\left.\text { ( } d_{\text {hxOD }}\right)\end{array}$ & 0.0095 & $\mathrm{~m}$ & $\begin{array}{l}\text { Heat Exchanger Tube Diameter } \\
\left.\text { ( } d_{\text {hxOD }}\right)\end{array}$ & 0.00635 & $\mathrm{~m}$ \\
\hline Fin Thickness & 0.00046 & $\mathrm{~m}$ & Fin Thickness & 0.00046 & $\mathrm{~m}$ \\
\hline Fin Pitch $\left(p_{\text {fin }}\right)$ & 0.00254 & $\mathrm{~m}$ & Fin Pitch $\left(p_{\text {fin }}\right)$ & 0.00254 & $\mathrm{~m}$ \\
\hline Twist Ratio & 9.84 & & Twist Ratio & 9.84 & \\
\hline ( $y=$ diameters $/ 180^{\circ}$ twist $)$ & & & ( $y=$ diameters $/ 180^{\circ}$ twist $)$ & & \\
\hline Slurry HX Length AB & 1.6 & $\mathrm{~m}$ & Gas HX Length AB & 1.25 & $\mathrm{~m}$ \\
\hline Slurry HX Length alane & 1.2 & $\mathrm{~m}$ & Gas HX Length alane & 1.0 & $\mathrm{~m}$ \\
\hline
\end{tabular}


Table 4

\begin{tabular}{lcc}
\hline \multicolumn{1}{c}{ Slurry Parameter } & Value & Units \\
\hline Inner Tube Diameter (Dinnerwall) & 0.0127 & $\mathrm{~m}$ \\
Outer Tube Diameter (Douterwall) & 0.0196 & $\mathrm{~m}$ \\
Wall Thickness & 0.00056 & $\mathrm{~m}$ \\
\hline
\end{tabular}

Table 5

\begin{tabular}{lcc}
\hline \multicolumn{1}{c}{ Component } & Value/Equation (Watts) & Operation \\
\hline $\begin{array}{l}\text { Volume Displacement Tank } \\
\text { Mixers }\end{array}$ & 20 & Start-Up Only \\
Pumps & $5.04 \times 10^{5} \Delta \mathrm{P}(\text { bar })^{*} \dot{m}_{\text {slurry }} / \rho_{\text {slurry }}$ & Variable \\
Radiator Blower & 91 & Constant \\
\hline
\end{tabular}

Table 6

\begin{tabular}{|c|c|c|c|}
\hline \multirow{2}{*}{ Component } & $\frac{\text { Mass Coefficient }}{(\mathrm{kg})}$ & $\begin{array}{c}\begin{array}{c}\text { Volume } \\
\text { Coefficient }\end{array} \\
\text { (I) }\end{array}$ & \multirow{2}{*}{ Determining Dimension } \\
\hline & & & \\
\hline $\mathrm{CH}$ Material & $\mathrm{M}$ & 0 & $\mathrm{M}=$ mass of $\mathrm{CH}, \mathrm{kg}$ \\
\hline Volume Exchange Tank & $51.9 * M / \rho+1.75$ & $M / \rho * 1000$ & $\begin{array}{c}M=\text { mass of } \mathrm{CH}, \mathrm{kg} \\
\rho=\text { slurry density, } \mathrm{kg} / \mathrm{m}^{3}\end{array}$ \\
\hline Reactor & \multicolumn{3}{|c|}{ Based on stainless steel and dimensions } \\
\hline Gas Radiator & $0.32 * \mathrm{~L}$ & $0.2 * \mathrm{~L}$ & $\mathrm{~L}=$ radiator length, $\mathrm{m}$ \\
\hline Slurry Radiator & $0.54 * \mathrm{~L}$ & $0.87^{*} \mathrm{~L}$ & $\mathrm{~L}=$ radiator length, $\mathrm{m}$ \\
\hline Ballast Tank & $0.17 * \mathrm{~V}$ & V & $\mathrm{V}=$ tank volume, Liters \\
\hline Ammonia Scrubber & $0.0032 * \mathrm{C}$ & $0.0068 * \mathrm{C}$ & $\mathrm{C}=$ concentration, $\mathrm{ppm}$ \\
\hline Borazine Scrubber & $0.0017^{*} \mathrm{C}$ & $0.0015^{*} \mathrm{C}$ & $\mathrm{C}=$ concentration, $\mathrm{ppm}$ \\
\hline Recuperator & \multicolumn{3}{|c|}{ Based on stainless steel and dimensions } \\
\hline Balance of Plant & 32.1 & 26.8 & \\
\hline
\end{tabular}


Table 7

\begin{tabular}{cccccc}
\hline $\begin{array}{c}\text { Solids } \\
\text { Loading } \\
\text { (wt\%) }\end{array}$ & $\begin{array}{c}\text { Reactor } \\
\text { Residence Time } \\
(\mathbf{m i n})\end{array}$ & $\begin{array}{c}\text { Auger } \\
\text { Speed } \\
(\mathbf{r p m})\end{array}$ & $\begin{array}{c}\text { Average Reaction } \\
\text { Temperature } \\
\left({ }^{\circ} \mathbf{C}\right)\end{array}$ & $\begin{array}{c}\text { Measured Alane } \\
\text { Conversion } \\
\text { (mol/mol) }\end{array}$ & $\begin{array}{c}\text { Modeled } \\
\text { Conversion Values } \\
\text { (mol/mol) }\end{array}$ \\
\hline $50 \%$ & 7.6 & 12 & 185 & $16 \%$ & $11 \%$ \\
$50 \%$ & 7.6 & 40 & 185 & $11 \%$ & $4.6 \%$ \\
$50 \%$ & 4.2 & 12 & 187 & $7 \%$ & $6.6 \%$ \\
$50 \%$ & 7.6 & 12 & 214 & $88 \%$ & $80 \%$ \\
$50 \%$ & 7.6 & 40 & 214 & $74 \%$ & $53 \%$ \\
$50 \%$ & 4.2 & 12 & 214 & $38 \%$ & $49 \%$ \\
$20 \%$ & 6.8 & 40 & 188 & $10 \%$ & $7.1 \%$ \\
$20 \%$ & 6.8 & 40 & 212 & $38 \%$ & $50 \%$ \\
$20 \%$ & 6.8 & 40 & 235 & $84 \%$ & $100 \%$ \\
$60 \%$ & 7.2 & 12 & 180 & $5 \%$ & $6.5 \%$ \\
$60 \%$ & 7.2 & 12 & 194 & $20 \%$ & $21 \%$ \\
$60 \%$ & 7.2 & 12 & 208 & $48 \%$ & $55 \%$ \\
\hline
\end{tabular}

\section{Table 8}

\begin{tabular}{lccc}
\hline & & \multicolumn{2}{c}{$\mathbf{A B}$} \\
\cline { 3 - 4 } Parameter & Units & $\mathbf{1}^{\text {st }}$ Equivalent & $\mathbf{2}^{\text {nd }} / \mathbf{3}^{\text {rd }}$ Equivalent \\
\hline Arrhenius Factor (Ai) & $\mathrm{s}^{-1}$ & $2.81 \times 10^{2}$ & $4.18 \times 10^{15}$ \\
Activation Energy (Ei) & $\mathrm{kJ} / \mathrm{mol}$ & 29.9 & 149 \\
\hline
\end{tabular}

\section{Table Captions}

Table 1. Reactor Parameters Used in the Reactor Model

Table 2. Reaction Parameters Developed from Experimental Data

Table 3. Parameters used in the Heat Exchanger Models

Table 4. Parameters used in the Recuperator Model

Table 5. Parasitic Power Requirements

Table 6. Parameters used to Calculate the Overall System Mass and Volume

Table 7. Comparison of Measured and Model Predicted Alane Conversion

Table 8. Updated Kinetic Parameters Based on Measured AB Values 


\section{Figure Captions}

Figure 1. Slurry AB System Process Flow Diagram

Figure 2. Batch Kinetic Results for a 35wt\% AB Slurry with Model Fits

Figure 3 Flow-Through Reactor Design used to Validate the Model

Figure 4. Comparison of Model Predicted Hydrogen Flow Rate to that Measured Experimentally for $20 \mathrm{wt} \%$ Alane Slurry

Figure 5. Comparison of Model Predicted Hydrogen Flow Rate to that Measured Experimentally for 20 wt\% AB Slurry

Figure 6. Prototypical Heat Exchanger used to Validate the Model

Figure 7. Comparison of the Experimental and Modeling Results for the Heat Exchanger

Figure 8. Ballast Tank Pressure as a Function of Time for 50 wt\% AB with the US06 Drive Cycle

Figure 9. Comparison of Hydrogen Required by the Drive Cycle and Hydrogen Produced by the Storage System for 50 wt\% AB with a US06 Drive Cycle

Figure 10. Temperature of Gas and Slurry Radiator Products for 50 wt\% AB with the USO6 Drive Cycle

Figure 11. Temperature of Gas and Slurry Radiator Products for 50 wt\% Alane with the US06 Drive Cycle

Figure 12. Sensitivity Analysis Comparing Heat of Reaction to the Predicted Onboard Efficiency for Both an Endothermic and an Exothermic System

Figure 13. Sensitivity Analysis Comparing the Slurry Storage Capacity to the Predicted System Gravimetric Capacity for Both an Endothermic and an Exothermic System 